\title{
A survey of the mycobiota of a natural Karoo pasture
}

\author{
C. ROUX* and K.T. VAN WARMELO**
}

Keywords: ecology, facial eczema, Karoo, litter, mycobiota, pasture, photosensitivity, South Africa

\author{
ABSTRACT
}

\begin{abstract}
The survey of a natural Karoo pasture from 1978 to 1982 showed that a wealth and variety of fungi were present in the semidesert environment. Hyphomycetes and Coelomycetes represented $45.8 \%$ and $34.6 \%$ respectively of the taxa identified. A total of 135 genera was identified of which Altenaria alternata. Cladosporium spp. and Fusarium spp. of the Hyphomycetes, Phoma spp., Ascochyta spp. and Camarosporium spp. of the Coelomycetes and Leptosphaerulina spp., of the Ascomycetes represented the most prevalent fungi in this order. This survey has shown conclusively that Pithomyces chartarum, which is associated with photosensitivity diseases of sheep, can always be recovered from the veld if the correct isolation techniques are employed. A number of new records for South Africa, as well as undescribed species, have been found, highlighting the necessity of correct methods and intensity of approach.
\end{abstract}

CONTENTS

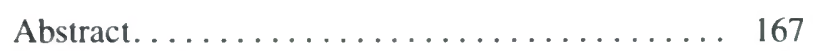

1. Introduction ................... 167

2. Materials and methods .............. 168

2.1. Sampling, monitoring sites and dates ...... 168

2.1.1. Sampling methods employed .......... 169

2.1.2. Sampling methods which proved inappropriate 169

2.1.2.1. Spore trapping . ............... 169

2.1.2.2. Exposure of Petri dishes .......... 169

2.2. Identification of fungi . . . . . . . . . 171

2.3. Meteorological data............... 171

2.4. Veterinary services.............. 171

2.5. Flowering plants sampled ........... 171

2.6. Sporidesmin assays . . . . . . . . . . 171

3. Results ...................... 171

3.1. Fungi recorded. ............... 171

3.1.1. From material directly planted out....... 171

3.1.2. From material planted out after washing .... 173

3.2. Sporidesmin assays ............... 173

3.3. Photosensitization ................ 173

4. Discussion. .................... 174

4.1. Fungi recorded................ 174

4.2. Photosensitization ............... 180

5. Conclusions ................. 180

Acknowledgements ................. 180

References ...................... 180

Appendix..................... 181

\section{INTRODUCTION}

Climatically the Karoo can be defined according to the Holridge System (Price 1975) as semi-arid to arid and warm to cool temperate. Characteristics are erratic, patchy rainfall and occasional unseasonal cold weather when snow may fall in the high-lying areas, even during midsummer (Figure 1).

\footnotetext{
* To whom correspondence should be addressed. Mycology Unit, Biosystematics Division, Plant Protection Research Institute, Agricultural Research Council, Private Bag X 134, 0001 Pretoria.

** Botany Department, Rand Afrikaans University, P.O.Box 524, Auckland Park. 2006 Johannesburg.

MS. received: 1997-02-21.
}

The original vegetation of the survey area, which according to Acocks $(1979,1988)$ was grassland, has largely been replaced by karroid veld, and there is general agreement that the process of deterioration is continuing with desertification advancing towards the northeast.

The flora of the region is rich in species (Acocks 1988) but the habitat is unpredictable with patches of temporary pioneer vegetation (Southwood 1977), comprising species such as Tribulus terrestris L., which become established when the first early summer rains fall.

'Geeldikkop', the hepatogenous photosentivity disease of mainly sheep, was first described by Hutcheon (1886). Theiler (1918) showed that ingestion of T. terrestris, especially wilted material, was directly implicated in the aetiology of the disease. He reported the presence of a Colletotrichum sp. on such material and linked it to the disease as a possible cause. According to Watt \& BreyerBrandwijk (1962) the ingestion of T. terrestris causes a condition similar to 'geeldikkop' called 'big head' reported from Colorado and Texas. The plants are high in saponins and thus inherently toxic. In New Zealand (Thornton \& Percival 1959; Thornton \& Ross 1959) Pithomyces chartarum from ingested grasses proved to be responsible for the development of hepatogenous photosentivity and facial eczema, which is very similar to 'geeldikkop'. Very few researchers have been successful in reproducing 'geeldikkop' under field conditions (Van Tonder et al. 1972). Kellerman et al. (1980) were able to show that the combination of $P$. chartarum and $T$. terrestris gave histopathological lesions similar to those found during natural outbreaks of the disease.

Fungi from litter in the Karoo have received little attention. Doidge (1950) reported only a few fungi from the Karoo, mainly collected by MacOwan in the Eastern Cape. On Lycium spp., amongst others, Puccinia lycii Kalchbr. was recorded. No fungi were recorded on Tribulus terrestris L. Pithomyces karoo Marasas \& Schumann (1972) was published after a study of litter from the Karoo.

Relatively few surveys of mycobiota have been published from South Africa. Eicker (1973) studied the my- 


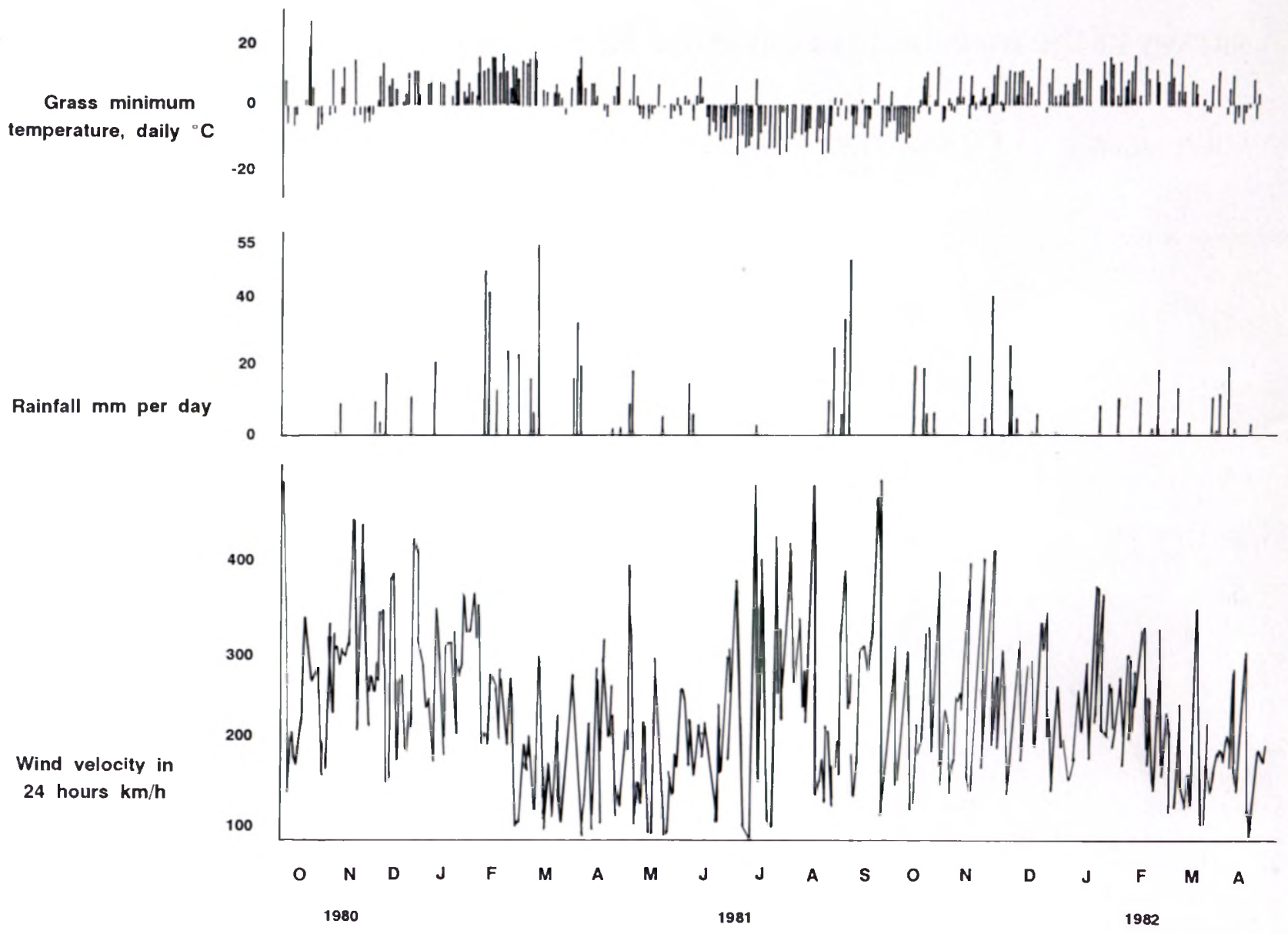

FIGURE 1.-Weather data for the period 1980/82, Middelburg. Grass minimum temperature, rainfall and wind velocity per day

cobiota of Eucalyptus maculata leaf litter. Papendorf \& Jooste (1974) described five species of fungi from wheat field debris after isolation by the dilution plate method. Eicker (1976) studied the mycoflora of Panicum coloratum associated with an outbreak of photosensitivity of sheep for an 11 month period.

Bezuidenhout (1977) studied the hyphomycetes (mitotic fungi, Hawksworth et al. 1995) associated with Cenchrus ciliaris L., a fodder grass, over an 11 month period. Van der Merwe et al. (1979) studied the aerospora of an Eragrostis curvula (Schrad.) Nees pasture in South Africa.

An interim report based on the present survey of Pithomyces chartarum was published stating that a further 315 isolates were tested for sporidesmin production in culture of which most did not produce the toxin (Annual Report 1981).

The present survey was initiated to determine the incidence of $P$. chartarum in natural Karoo pasture at a time when 'geeldikkop' was likely to occur. The original scope of this study was increased considerably when it became apparent that much valuable information could be gained if a general survey of the mycobiota of the area was done.

\section{MATERIALS AND METHODS}

\subsection{Sampling, monitoring sites and dates}

The survey was conducted at the Grootfontein Agricultural College Farm, Middelburg, Eastern Cape Prov- ince. Sampling and monitoring were done over a period of four seasons during which weekly or fortnightly samples were collected. The sampling procedure involved taking samples from up to seven different plants as well as litter, at three points (1978/79) and later in two camps of a hectare each from 1979 onwards (Table 1).

\section{$1978 / 79$ survey}

Three sampling points, A, B and C were chosen after completion of a botanical survey of an area where Tribulus terrestris occurred. The nature of the communities at the sampling points varied significantly regarding crown cover, basal cover and density.

Point A was situated in a community with a reasonably high density of perennial Karoo bushes. Therefore, the crown cover was such that wind movement between the individual bushes was possible. The basal cover of $T$. terrestris was fairly high but decreased with time.

Point B was situated in a very dense community of perennial Karoo bushes which allowed virtually no wind movement at soil level. Very few T. terrestris and other pioneer plants, such as Galenia sarcophylla, were present.

Point C was situated in an area where only one Lycium cinereum bush of $1.5 \mathrm{~m}$ in height was present besides $T$. terrestris. Virtually no other vegetation was present at this point at the onset of the survey. 
TABLE 1.-Sampling dates and numbers of sampling units collected

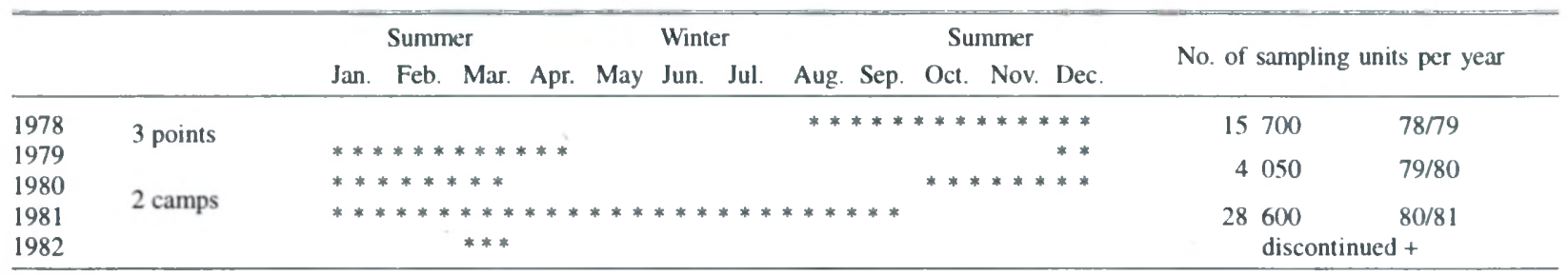

+ The survey was discontinued because of the third successive year of drought and the resulting deterioration of the vegetation.

Weekly samples of litter were collected, including $T$. terrestris when present, after rains had fallen during December 1978. A total of 34 samples of litter and 20 of $T$. terrestris plants were studied during this period of seven months.

\section{9/80 survey}

Shifting of plant communities at the points previously chosen necessitated another approach. It was decided to establish two camps (A and B) of one hectare each; the one (A) with a fair cover of $T$. terrestris, the other (B) without. Five sheep were put into Camp A and the following plants were sampled: the Karoo bushes Galenia sarcophylla, $G$. procumbens, Felicia muricata and Lycium cinereum and the grasses Eragrostis lehmanniana and Cynodon incompletus. Other plant materials sampled were unidentified litter and $T$. terrestris. Initially Camp B contained very little $T$. terrestris and, because of well established stands of perennials such as Felicia muricata and Lycium cinereum, was less susceptible to invasion by $T$. terrestris and other pioneers. The density of the communities in Camp B was much higher than in Camp A, and T. terrestris was only found in the corner of the camp adjacent to Camp A. Very few Pentzia spp. and other typical Karoo bushes grew in the two camps.

Sampling took place from December 1979 to the end of March 1980 on a fortnightly basis.

\section{0/81 survey}

This survey started in September 1980 and was continued through 1981. A total of 52 weekly samples was collected and studied from each of the two camps. This time every plant species named in the 1979/80 survey was, however, sampled and studied individually. Thus four species of bushes, two species of grasses, litter and, when available, $T$. terrestris were sampled for a full calendar year.

\section{1/82 survey}

This survey was a continuation of the 1980/81 survey, and continued to the end of March 1982

\subsubsection{Sampling methods employed}

Samples were taken up to a height of $150 \mathrm{~mm}$ which corresponds to the vertical zone grazed by merino sheep. Care was taken to lift litter from the soil surface so as to pick up as few eelworms as possible. The camps were sampled at random to obtain representative samples. If wet, due to rain or dew, the samples were sun-dried before packing into paper bags, every sample from each plant species packed separately, and locality, date and species were noted. Samples were then posted to Pretoria which took approximately 10 days.

The sampling units used were individual leaves, leaflets and $10 \mathrm{~mm}$ lengths of stems and grass blades. The material was sorted and samples from as many different leaves and stems as was possible were taken. Fifty units from each of the samples were planted out directly on potato carrot agar (PCA) (Johnston \& Booth 1983) to which $125 \mathrm{mg} / \mathrm{l}$ Albamycin T (Upjohn) had been added prior to autoclaving. Initially some samples from Camps $A$ and $B$ were first washed by shaking in tap water mixed with Teepol (Shell Chemicals) 1:100 in a wrist shaker for 10 minutes to dislodge superficial conidia. The washed material was planted out directly after this treatment. The first five samples collected during the 1980/81 survey were studied this way.

The plates were incubated for a period of seven days at $24^{\circ} \mathrm{C}$ with intermittent mixed near-UV and daylight fluorescent light from a height of $300 \mathrm{~mm}$ on a $12 \mathrm{~h} / \mathrm{d}$ cycle. The presence of fungi on the material studied was noted and isolations made of $P$. chartarum and other noteworthy fungi. Chemical assays for sporidesmin, the toxin produced by $P$. chartarum, were done according to the method of Marasas et al. (1972) on a number of the isolates. Some of these cultures were also used to produce bulk cultures with which to dose sheep.

\subsubsection{Sampling methods which proved inappropriate}

\subsubsection{Spore trapping}

A Burkard volumetric spore trap was operated from 26-01-1976 to 26-02-1976 on a 24 hour basis in the toxic camp. Only one conidium of $P$. chartarum was collected (Roux 1977). It was later found that the spore trap had to operate too high above the ground to pick up the conidia released at a much lower level. No spore trap functioning on a suction principle can operate in a sandy environment at a low level. The use of a spore trapping device was therefore not employed further.

\subsubsection{Exposure of Petri dishes}

This technique had the dual advantage that it gave the best indication of how many airborne conidia there were, and isolates obtained in this manner were alive and could be used for sporidesmin assays almost right away. However, the distance between the sampling site at Grootfontein and Pretoria made this an impracticable method. It was noted that under windy conditions the Petri dishes 

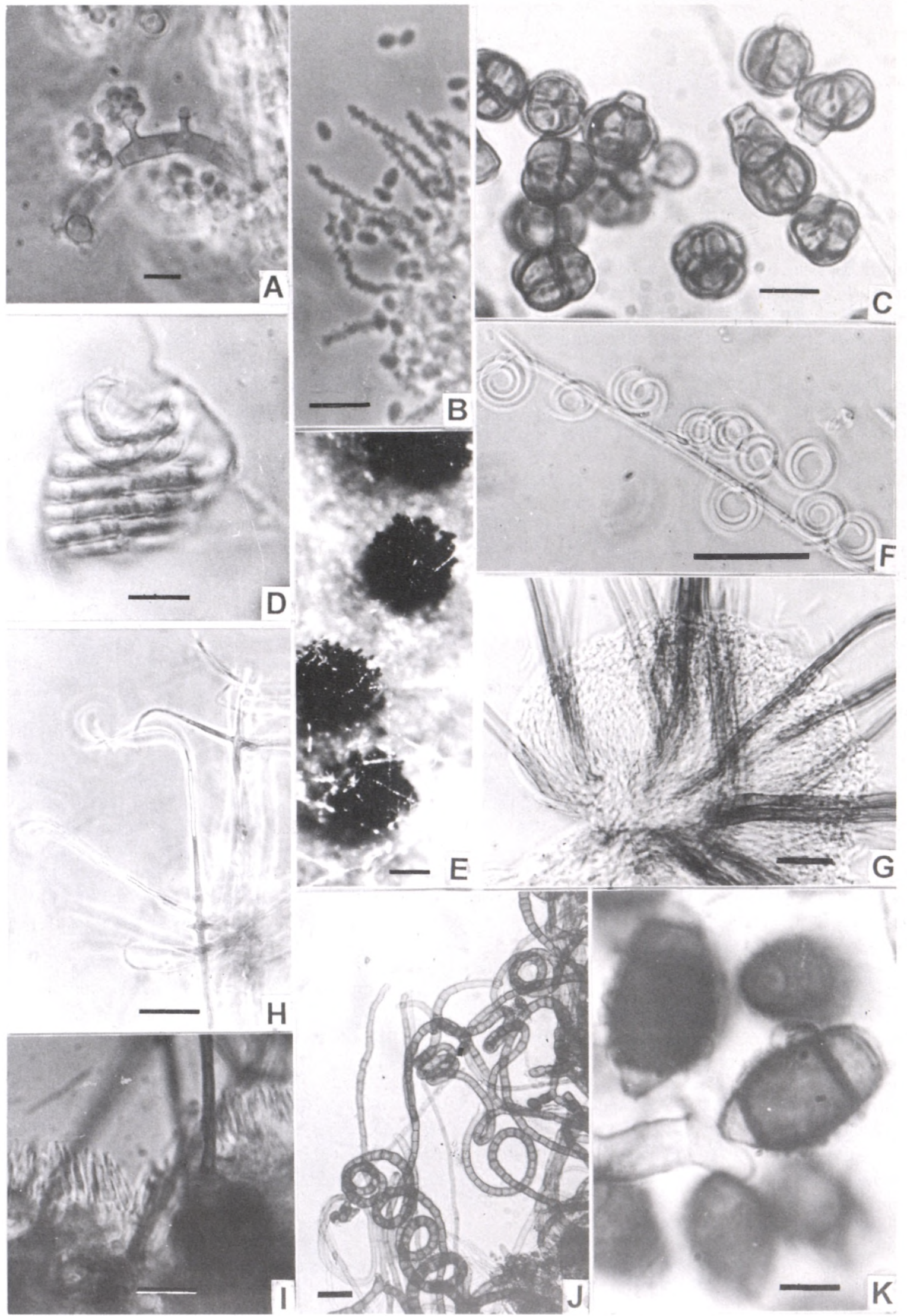

FIGURE 2.-Hyphomycetes from the fungal survey of the Karoo. A, Cladorhinum foecundissimum: distinct collarette on phialide and conidia in mucilaginous ball; B, Beauveria bassiana: conidiogenous cells with denticles bearing conidia; C, Cerebella andropogonis: conidia with distinct basal pedicels; D, Helicoon sessile: hyaline helicospore on slender conidiogenous cell; E, Pithomyces chartarum: conidia confined to ascostromata of Leptosphaerulina chartarum on blade of Cynodon incompletus; $\mathrm{F}$, Helicomyces roseum: hyaline helicospores on conidiophore; G, Volutina concentrica: coelomycete-like fungus with stipe, setae and conidia; H, Gyrothrix flagella: flagellum-like recurved setae in whorls; I, G. flagella: conidiogenous cells at bases of setae; J, Taeniolella sp.: characteristically curved conidia; K, Curvularia tuberculata: conidiogenous cell bearing conidium with tubercles. Scale bar: $50 \mu \mathrm{m}$. 
could be opened for 10 minutes whereas 20 minutes in quiet conditions were needed to give the required results. A larger variety in fungal species was picked up in open patches than amongst dense undergrowth. On the lee side of bushes much fewer conidia could be collected. $P$. chartarum was collected in every Petri dish exposed.

\subsection{Identification of fungi}

The fungi were initially identified at magnifications of $25 \times$ and $50 \times$ using a Zeiss dissecting microscope. Verification of identifications was done with a similar make of research microscope. Material was mounted in lactophenol (Johnston \& Booth 1983) but from 1980 the coelomycetes (mitotic fungi, Hawksworth et al. 1995) were mounted in ammonium hydroxide with $3.5 \%$ erythrosin (Sutton 1980) to facilitate identification based on conidiogenesis. Photomicrographs were obtained using an Olympus microscope camera and Ilford Pan F film.

The fungi were identified using standard monographs (Booth 1971; Ellis 1971, 1976; Subramanian 1971; Sutton 1980; Sivanisan 1987).

\subsection{Meteorological data}

Members of the Agricultural Meteorological Division of the Soils and Irrigation Research Institute stationed at Grootfontein recorded and monitored the weather from a casual station in the vicinity. This was equipped with a Stevenson Screen housing a thermohygrograph to record the daily minimum and maximum temperature, an anemometer, manual and automatic rainfall meters and a grass minimum thermometer.

\subsection{Veterinary services}

Veterinarians stationed at the Regional Diagnostic Laboratory of the Division of Veterinary Services inspected the sheep from time to time for clinical signs of 'geeldikkop'.

\subsection{Flowering plants sampled}

Tribulus terrestris L. (Zygophyllaceae): known as caltrop in the USA, three-cornered jack in Australia and also as Mexican sand-burr (Watt \& Breyer-Brandwijk 1962); is notorious for causing disease in sheep and goats; is an annual pioneer plant with a sprawling habit which forms a ground cover; has composite leaves consisting of up to 11 small pinnae covered adaxially with long adpressed unicellular hyaline hairs.

Galenia sarcophylla Fenzl (Aizoaceae): a semisucculent, herbaceous ground cover with leaves covered with unicellular and multicellular hairs; is highly palatable to grazing animals and is preferred to $T$. terrestris; occupies a similar ecological niche as T. terrestris.

Galenia procumbens L.f. (Aizoaceae): a hardy erect shrub about $0.5 \mathrm{~m}$ high with small, smooth, simple leaves; is highly palatable to sheep.

Felicia muricata Thunb. (Asteraceae): a multistemmed perennial plant with simple, very small smooth leaves with a sticky surface which serves as an ideal spore trap; is highly palatable to grazing animals.

Lycium cinereum Thunb. sensu lato (Solanaceae): an erect perennial plant, with woody branches which can reach a height of more than a metre; has simple, smooth leaves and produces small red berries after flowering in midsummer; in the young stages it is preferentially grazed but is shunned when older and harder, because of its thorny nature; when grazed heavily this species is similar to the smaller Karoo bushes.

Cynodon incompletus Nees (Poaceae): a stoloniferous perennial with a sprawling habit similar to $T$. terrestris and $G$. sarcophylla; under adverse conditions the plant is an annual.

Eragrostis lehmanniana Nees var. lehmanniana (Poaceae): an erect tussock grass which is intensively grazed; usually perennial but it may be annual under adverse conditions.

\subsection{Sporidesmin assays}

A total of 1005 isolates of $P$. chartarum were made for toxin production testing. Of these, 437 isolates were selected and grown on semisynthetic broth (Di Menna et al. 1970) for three weeks under near-UV and daylight fluorescent tubes on a $12 \mathrm{~h} / \mathrm{d}$ cycle from a height of 300 $\mathrm{mm}$ at $20^{\circ} \mathrm{C}$. The extraction procedure described by Marasas et al. (1972) was used.

\section{RESULTS}

\subsection{Fungi recorded}

\subsubsection{From material directly planted out}

All mycobiota identified during this survey are listed in the Appendix. Records of genera and species that were new for South Africa are marked.

The main groups and their incidence in relation to the seasons during the 1980/81 survey are given in Table 2. The total number of genera identified and the percentage representation of classes is given in Table 3. Tables 5, 6 and 7 give complete information regarding the percentage occurrence of the majority of identified fungi on particular substrates for the surveys from 1978 to 1981 .

Some of the more unusual fungi identified have been illustrated in Figure 2 (Hyphomycetes) and Figure 3 (Coelomycetes). Conidia of $P$. chartarum localized on the ascostromata of Leptosphaerulina chartarum are especially noteworthy (Figure 2E).

Weather data recorded from October 1980 to April 1982 are shown on Figure 1. Seasonal fluctuations characterized most of the more prevalent fungi recorded. The seasonal incidences have been summarized in Table 2 where fungi which occurred continuously can be identified as having a peak in a particular season, e.g. summer or winter, as well as on what substrate they occurred. $P$. chartarum occurred frequently during the first years of 

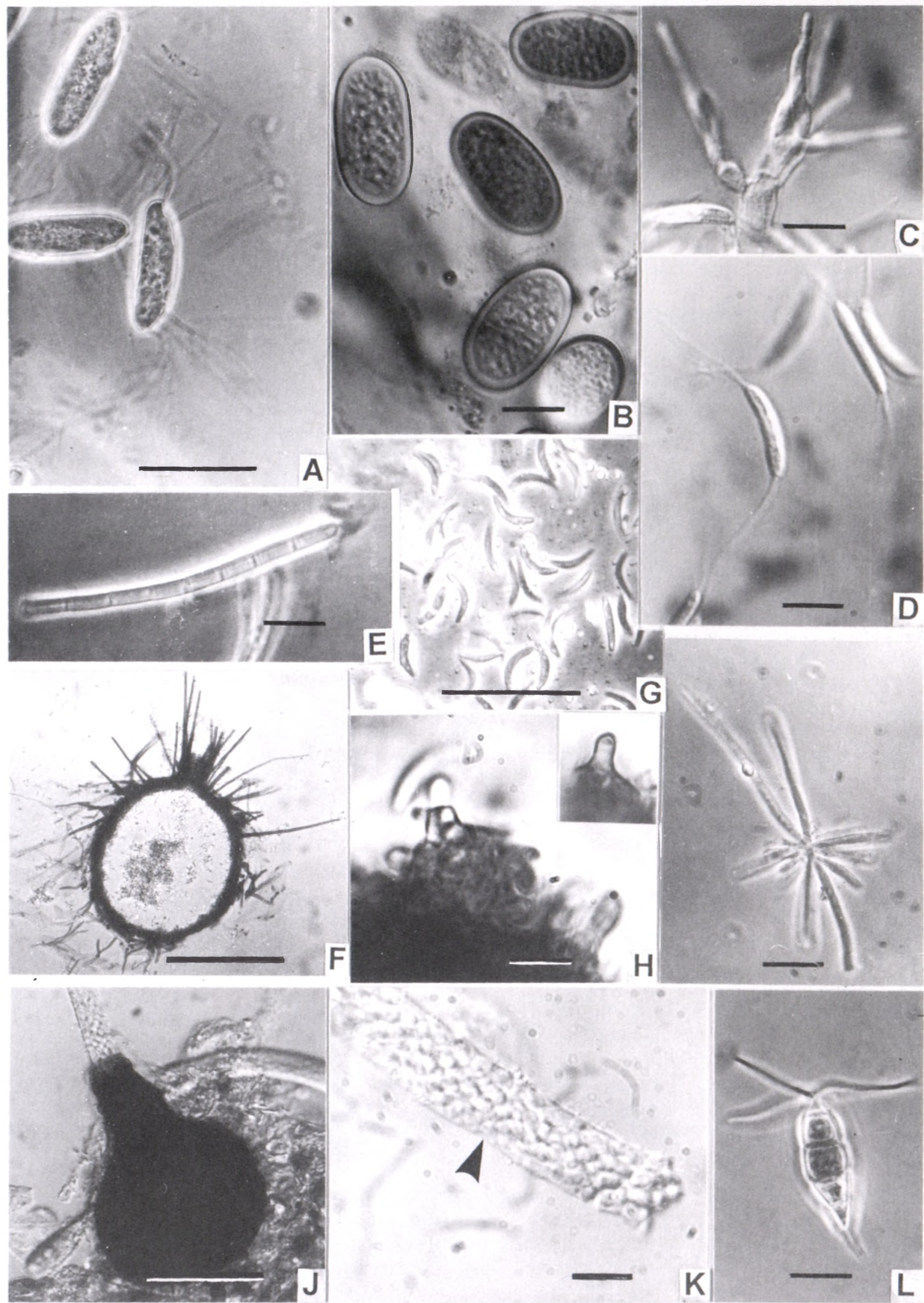

FIGURE 3.-Coelomycetes from the fungal survey of the Karoo. A, Chaetospermum chaetosporum: conidia with hilum and appendages on apical and basal ends of conidium; B, Melanophoma sp.: conidia with distinct epispore; C, Dinemasporium sp.: conidiogenous apparatus with collarette on phialide, base of conidium protruding; D, Dinemasporium strigosum: conidia showing apical and basal appendages; E, Septoriella junci: conidium with apical mucilaginous appendages and septa clearly visible; F, Pyrenochaeta sp.: longitudinal section through pycnidium showing setae surrounding ostiole; G, Pseudoseptoria sp.: falcate conidia; $\mathrm{H}$, Pseudoseptoria sp.: conidiogenous cell showing developing conidia and (inset) characteristically long neck with multiple annellations; I, cf. Tetranacrium sp.: conidium with more than usual number of divergent arms; J, Sarcinulella sp.: pycnidium with characteristic tendril of conidia enveloped in a mucilaginous tube; $\mathrm{K}$, Sarcinulella sp.: detail of conidial tendril with constriction caused by individual sac (arrowed); L, Pestalotiopsis sp.: conidium with apical three-armed appendage and single basal appendage. Scale bars: A, F, G, J, $50 \mu \mathrm{m} ; \mathrm{B}-\mathrm{E}, \mathrm{H}, \mathrm{I}, \mathrm{K}, \mathrm{L}, 10 \mu \mathrm{m}$. 
TABLE 2.-Main groups of fungi recorded in the 1980/81 survey

\section{Winter fungi}

Alternaria spp. Aureobasidium spp

Camarosporium spp.

Cladosporium spp

Epicoccum purpurascens

Leptosphaerulina spp

Rhizoctonia spp.

Autumn fungi

Fusarium spp.

Metarhizium anisopliae

Myrothecium spp

Leptosphaerulina spp

\section{Summer fungi}

Camarosporium spp.

\section{No obvious pattern}

Alternaria spp.

Mycosphaerella spp.

\section{Fungi always present}

Drechslera spp.

Pithomyces chartarum

Phoma spp.

Stauronema spp.
On Lycium in Camp A

High on all substrates except Tribulus and litter

High on Galenia procumbens in Camp A

High on all substrates in Camp B

On Cinodon in Camps A \& B

Highest on $G$. procumbens in Camp B

High on litter from April onwards in Camp B

High on F. muricata and lower plants (Fig. 1) in Camp B

On all except Tribulus, Cinodon and Felicia in Camp A; disappeared after autumn in Camp B

Peak in late summer in Camps A \& B: low on litter, peak on Tribulus in late summer in Camp A

In Camp A low close to the soil on Galenia sarcophylla and litter; in Camp B high on G. procumbens; lowest on prostrate plants, viz. G. sarcophylla and litter

Highest on Galenia procumbens, peak in mid-summer, consistent on litter in Camp B; different patterns on the different substrates; in Camp A, the lowest on litter all year round

On all substrates except Lycium cinereum in Camp B: slightly higher in winter in Camp A Inconsistent on most substrates, high on Lycium in Camp B

High on Cynodon, low but present on other substrates in Camps A \& B

Higher in Camp A; always present on all substrates but at very low levels

Consistent in Camp B; lowest on $G$. procumbens in Camp A

Consistent on litter, peaks on Felicia, Eragrostis, Cynodon in Camp B; inconsistent in Camp A the survey, reaching numbers of more than $80 \%$ but declined steadily as the drought continued. It could still, however, be isolated from material in each camp. Galenia procumbens, Felicia muricata and Cynodon incompletus were the hosts with the highest numbers of Leptosphaerulina sp. recorded throughout the 1980-1981 season, reaching peaks during the winter months. The weather kept to the same pattern over the entire survey and is shown in the record for the period October 1980 to April 1982 in Figure 1.

Average occurrences of the dominant fungi at the various sampling points and areas are presented for the $\mathrm{Hy}$ phomycetes (Figure 4), for the Coelomycetes and the genus Leptosphaerulina (Figure 5), the only ascomycete which occurred continuously for the periods $78 / 79,79 / 80$ and $80 / 81$.

Sudden fluctuations can be attributed to personal sampling error when someone other than the regular sampler had collected the samples.

\subsubsection{From material planted out after washing (Table 4)}

P. chartarum does not, under normal circumstances, colonize living leaves in the Karoo and usually occurs as

TABLE 3.-No. of genera identified and percentage representation of classes during entire survey

\begin{tabular}{lcc}
\hline Taxa* & No. of genera & $\%$ of total \\
\hline Myxomycetes & 4 & 3.25 \\
Zygomycetes & 5 & 4.07 \\
Ascomycetes & 11 & 8.94 \\
Hyphomycetes & 55 & 44.72 \\
Coelomycetes & 45 & 36.59 \\
Mycelia Sterilia & 3 & 2.44 \\
Total & 123 & \\
\hline
\end{tabular}

* The Basidiomycetes were not included in the calculation because identification to genus level was not possible. superficial conidia on exposed plant surfaces. Surface sterilization is therefore not an appropriate technique when looking for this organism. However, the fact that it can occur as an endophyte would add another dimension to its versatility as it is already known as a pathogen of rice (Sutton \& Gibson 1977) and a saprophyte.

\subsection{Sporidesmin assays}

A total of 36 isolates or $7.5 \%$ of the 1005 isolates of $P$. chartarum was positive, and the highest yield was 40 $\mathrm{mg} / \mathrm{l}$ sporidesmin. Most isolates, however, gave $10 \mathrm{mg} / \mathrm{l}$ or less sporidesmin under these conditions. The telcomorph Leptosphaerulina chartarum also produced 10 $\mathrm{mg} / \mathrm{l}$ sporidesmin under the standard conditions.

\subsection{Photosensitization}

Although Merino sheep were kept in at least one sampling area at a time, no photosensitization on a clinical level was reported. This is supported by the weather data obtained, which confirmed that no 'danger period' for the outbreak of photosensitization had occurred according to the conditions given by Crawley \& Woolford (1965).

TABLE 4.--Percentage of pieces of plant material contaminated with Pithomyces chartarum after being washed thoroughly

\begin{tabular}{lcc}
\hline Plant material & Camp A & Camp B \\
\hline Plant litter & 3.7 & 4.0 \\
Tribulus terrestris & \multicolumn{2}{c}{ Not available } \\
Cynodon incompletus & 2.0 & 2.8 \\
Eragrostis lehmanniana & 3.0 & 4.4 \\
Lycium cinereum & 6.0 & 2.4 \\
Galenia procumbens & 3.0 & 1.5 \\
Galenia sarcophylla & 9.3 & 16.0 \\
Felicia muricata & 0.6 & 4.0 \\
\hline
\end{tabular}




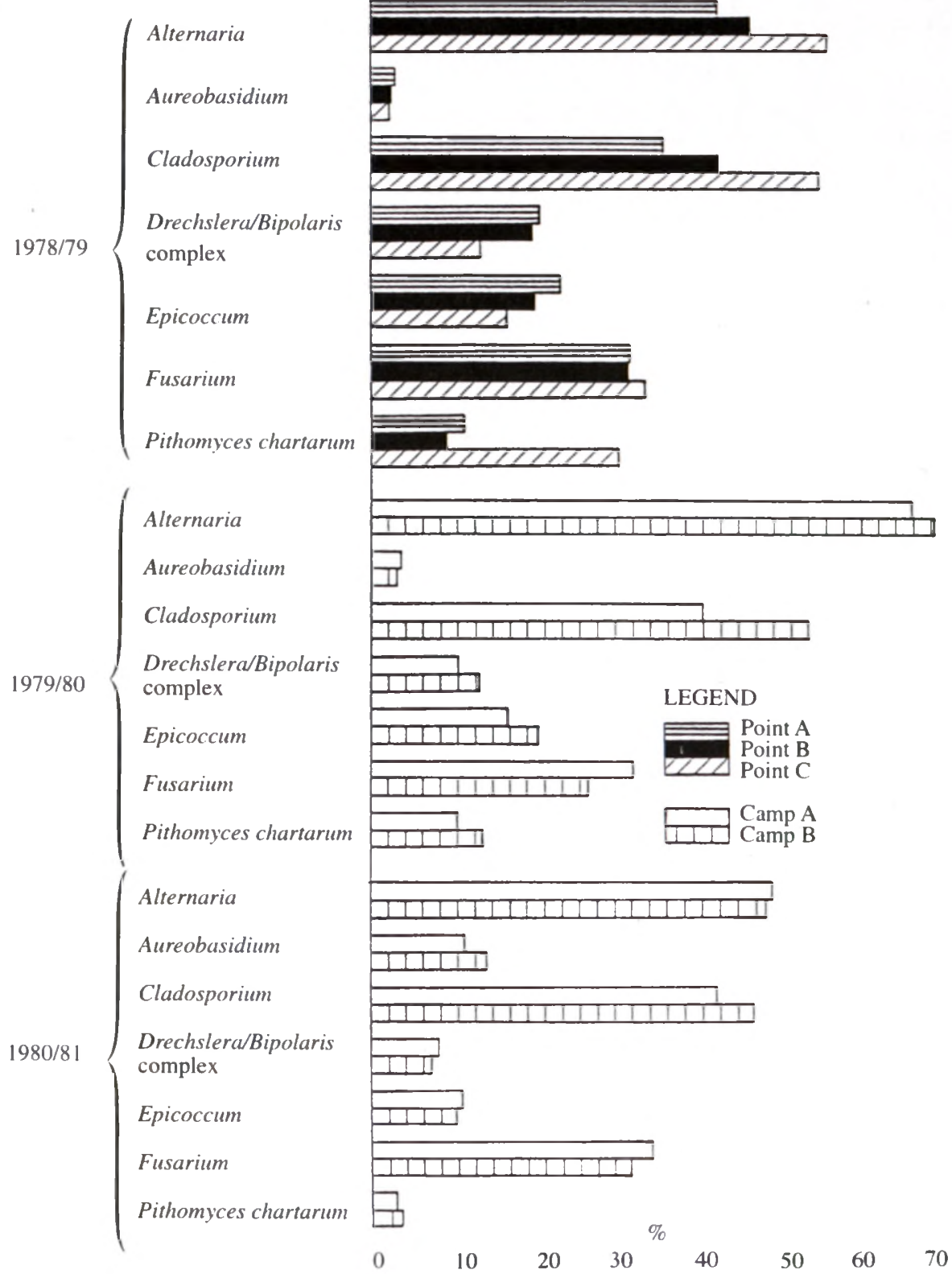

collected under conditions not usually considered conducive to the maintenance of an extensive fungal population.

\subsection{Fungi recorded}

A significant finding of this survey was that the Coelomycetes were abundant and diverse and that the number of genera found was nearly equal to that of the Hyphomycetes (Table 5). The 46 genera of identified Coelomycetes (Appendix) and 63 genera of the Hyphomycetes included 24 genera of the Coelomycetes and four genera and 14 species of Hyphomycetes newly recorded for South Africa (see Appendix). Two new records of Ascomycetes were noted, including one new species, Leptosphaerulina chartarum Cec.Roux, which is the teleomorph of Pithomyces chartarum (Roux 1985a).

The total of 63 known genera of Hyphomycetes found in this survey is not as low as it would appear when compared with other surveys, for example that of Bezuidenhout (1977), which were done on either irrigated lands or under temperate conditions. The fungi in this survey were
The fungi with consistently high counts were Phoma spp., Alternaria alternata and Cladosporium spp. (Figures 4 \& 5). Pugh \& Mulder (1971) also encountered Alternaria tenuis, Aureobasidium pullulans, Cladosporium herbarum, Epicoccum nigrum and Phoma typharum as initial colonizers of Typha latifolia L. Populations of Phoma spp. increased over the years which could be due to their being better adapted to the increasingly dry conditions. Ascochyta spp. and Camarosporium spp. increased with time and then levelled off. The incidence of Bipolaris spp. (including related genera such as Drechslera and Exserohilum), Epicoccum nigrum and Pithomyces chartarum declined over the study years, although these organisms still occurred consistently. The only Ascomycete which occurred consistently was the genus Leptosphaerulina which also declined eventually (Table 7). It is possible that $P$ chartarum, which was also present throughout the survey, could have been produced by $L$. chartarum, which was then counted as $P$. chartarum rather than as $L$. char- 


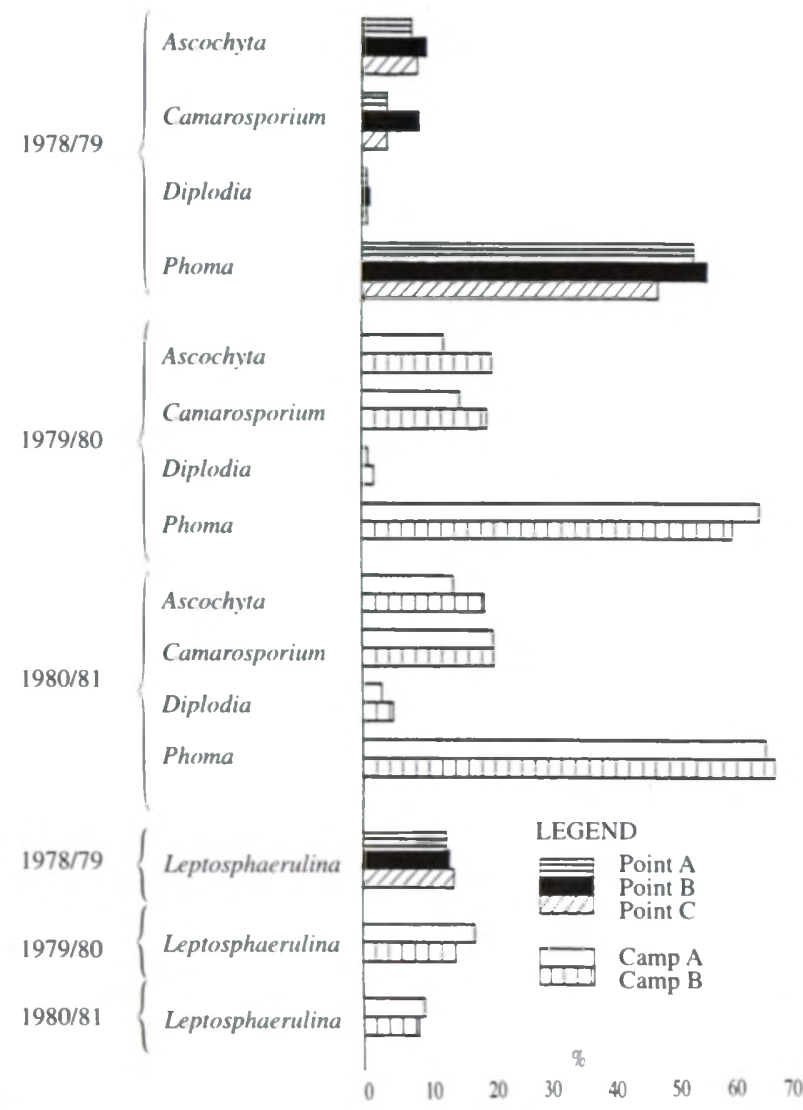

FIGURE 5-Most prevalent Coelomycetes recorded from 1978-1981 including Leptosphaerulina spp., the only consistent Ascomycete.

tarum, when considering the nature of the sporulation straight from the ascospores. The correlation between the incidences of these two fungi, the ana- and teleomorph (mitotic and meiotic, Hawksworth et al. 1995) states, was therefore most significant.

The plant communities studied contain a wealth of fungi, many previously unrecorded. Noteworthy was the occurrence of albino strains of the common species $\mathrm{Al}$ ternaria altermata, Cladosporium cladosporioides and Sta- chybotrys chartarum.

The Hyphomycetes (Table 5) occurred widely and were not as restricted regarding substrate as the other groups encountered. Unusually low incidences were, however, noted for species of Aspergillus, Penicillium and Trichoderma.

Coelomycetes (Table 6) recorded on a wide range of substrates were the following: Ascochyta spp., Camarosporium spp., Diplodia spp. and Phoma spp.

The highest incidence of the most prominent genera was noted during autumn and winter (Table 2). This could be explained by the fact that free water in the form of dew and rain was available for longer periods, thus enhancing the growth of fungi. Grass minimum temperatures recorded were substantially lower in winter than in summer. Highest rainfall occurred during late summer and autumn, seasons in which the wind tended to subside (Figure 1 ), thus reducing evaporation.
Nematophagous fungi, such as Dactylella and Candelabrella spp., were found. Large numbers of eelworms were inadvertently picked up with some of the samples and interfered with the counting of the fungi present on the substrate studied.

The entomophagous fungi Beauveria bassiana and Metarhizium anisopliae were frequently found but only in small numbers. B. bassiana is an important component of a complex of natural enemies of the Karoo caterpillar Loxostege frustalis Zeller (Möhr 1982). During the survey the Middelburg District experienced drought for three successive years. Consequently the ground cover decreased drastically and the unstable sandy soil was disturbed by wind and hoof action. The conidea of B. bassiana, associated with the early subterranean pupal stage of the karoo caterpillar, were therefore set free into the atmosphere in increasing numbers.

The increase in the number of species of Hyphomycetes from 1980 onwards can also be attributed to the worsening drought conditions which resulted in greater amounts of litter being deposited. The litter became very rich in fungi which would otherwise probably not have been isolated, as the litter fraction represented all the plant material available at the various sampling points and thus included all plant species not sampled separately. It is, therefore, understandable that mycobiota of litter should be much more varied than those of single plant species.

Aspergillus flavus deserves special mention. This toxigenic fungus was very common in animal feeds from all over South Africa examined for mycotoxicological fungi during the entire survey period (Roux 1985b), but it was not recorded in the present survey during the normal rainy season of $1978 / 79$.

In the initial trial run during which material was planted out after washing, $P$. chartarum was found to be an endophyte. This is even more significant in the light of the subsequent discovery of the teleomorph. Thus $P$. chartarum, or $L$. chartarum as it should now be known, can survive unsuitable conditions protected by the leaves of live plants and possibly sporulate when they die. The fact that the conidial stage of $L$. chartarum was found in tissues from all live plants studied is most significant.

Due to the large number of samples and the primary emphasis on Pithomvces chartarum, species of common genera such as Fusarium, Bipolaris and Leptosphaerulina were not recorded separately. The most common species of Fusarium was $F$. moniliforme followed by $F$. subglutinans. In the Bipolaris group the following species were identified: B. cynodontis, B. halodes, B. hawaiiensis, $B$. papendorfii, B. zeicola, Drechslera phlei and Exserohilum rostrata. $B$. halodes was the most prevalent.

Hering (1965) stated that though he had isolated a number of Ascomycetes and Coelomycetes, they failed to grow on the isolation medium. Experience obtained during this study showed that any bacteriostatic agent other than a few drops of lactic acid per Petri dish could completely inhibit the growth of some Coelomycetes. This could explain why the numbers of the Coelomycetes re- 


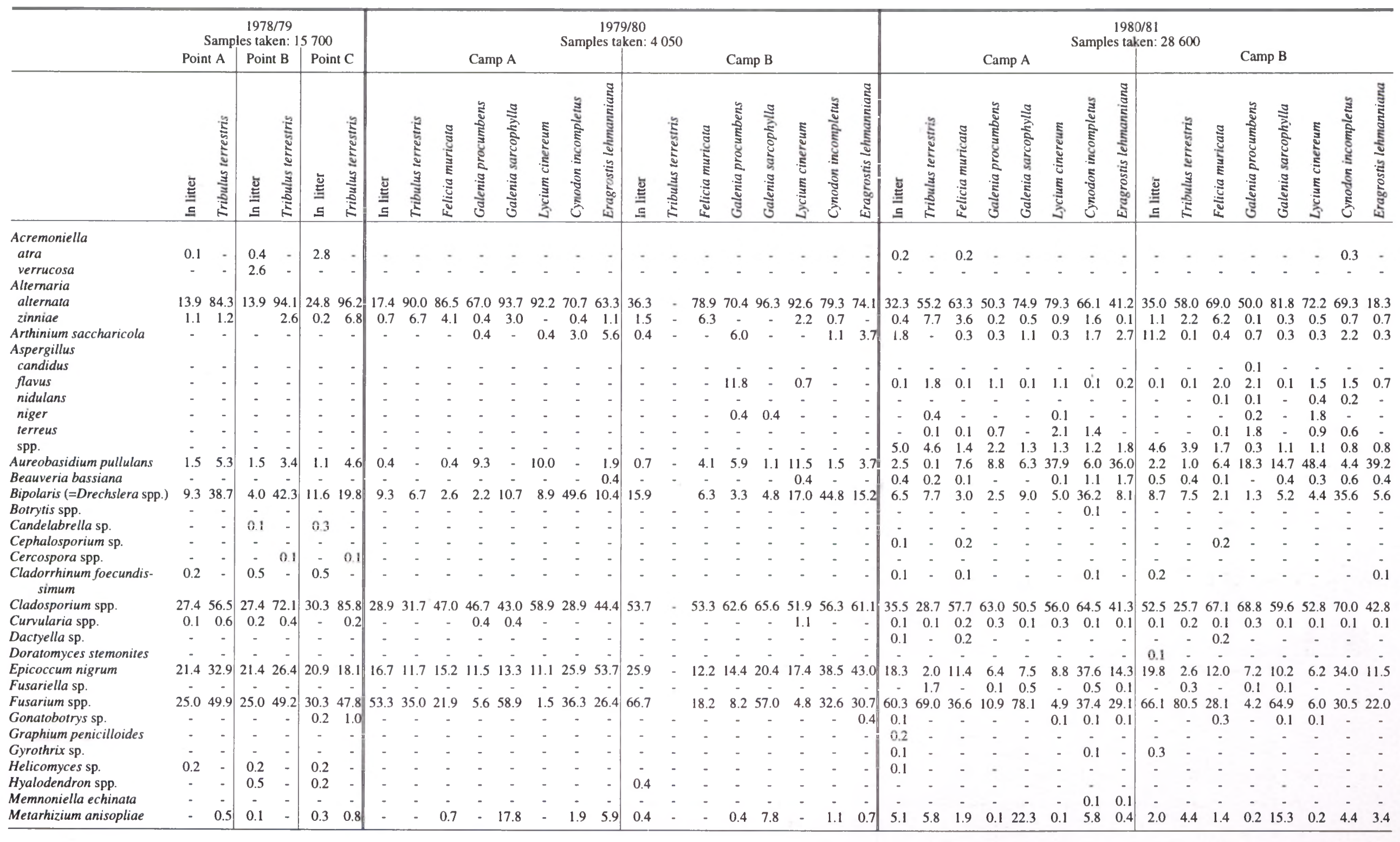


TABLE 5.-Percentage of the total number of samples taken for the Hyphomycetes (1978-1981) (continued)

\begin{tabular}{|c|c|c|c|c|c|c|c|c|c|c|c|c|c|c|c|c|c|c|c|c|c|c|c|c|c|c|c|c|c|c|c|c|c|c|c|c|c|c|}
\hline & \multicolumn{6}{|c|}{$\begin{array}{c}\text { 1978/79 } \\
\text { Samples taken: } 15700\end{array}$} & \multicolumn{16}{|c|}{$\begin{array}{c}\text { 1979/80 } \\
\text { Samples taken: } 4050\end{array}$} & \multicolumn{16}{|c|}{$\begin{array}{c}\text { 1980/81 } \\
\text { Samples taken: } 28600\end{array}$} \\
\hline & \multicolumn{2}{|c|}{ Point A } & \multicolumn{2}{|c|}{ Point B } & \multicolumn{2}{|c|}{ Point C } & \multicolumn{8}{|c|}{ Camp A } & \multicolumn{8}{|c|}{ Camp B } & \multicolumn{8}{|c|}{ Camp A } & \multicolumn{8}{|c|}{ Camp B } \\
\hline & $\begin{array}{l}\text { 䔍 } \\
\underline{\Xi}\end{array}$ & 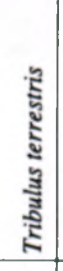 & $\begin{array}{l}\text { 总 } \\
\text { ভ }\end{array}$ & 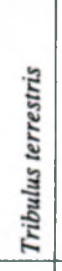 & $\begin{array}{l}\text { ⿹气巳 } \\
\text { S }\end{array}$ & $\begin{array}{l}\text { हू } \\
\text { s. } \\
\text { है } \\
\text { है }\end{array}$ & 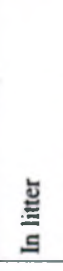 & 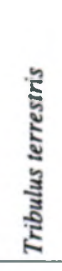 & 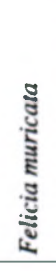 & 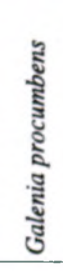 & 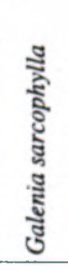 & 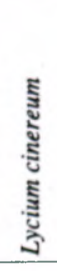 & 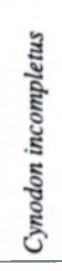 & 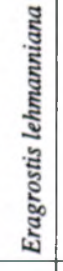 & $\begin{array}{l}\text { 䔍 } \\
\underline{\Xi}\end{array}$ & 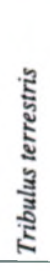 & 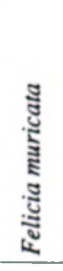 & 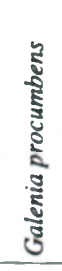 & 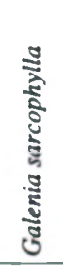 & 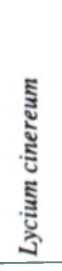 & 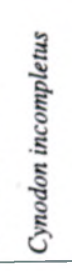 & 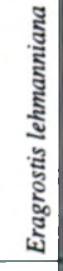 & $\begin{array}{l}\text { 氖 } \\
\text { 品 }\end{array}$ & 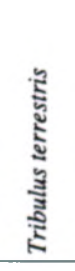 & 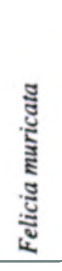 & 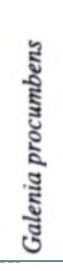 & 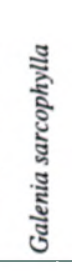 & 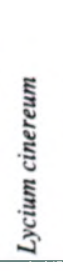 & 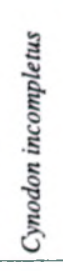 & 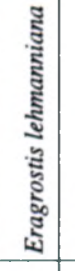 & $\begin{array}{l}\text { 鴶 } \\
\text { S }\end{array}$ & 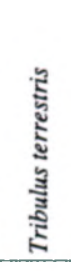 & 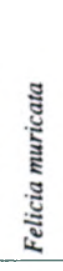 & 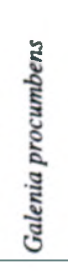 & 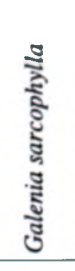 & 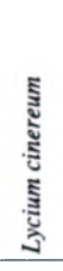 & 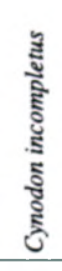 & 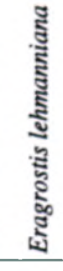 \\
\hline Monacrosporium sp. & 0.4 & - & 0.5 & - & 1.0 & - & 0.7 & - & - & - & - & 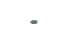 & - & - & - & - & . & - & - & - & 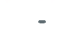 & 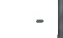 & 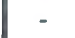 & - & - & - & - & 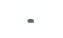 & - & 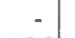 & - & - & - & - & - & - & - & . \\
\hline on & - & -1 & - & - & - & $\cdot$ & & - & - & - & - & - & - & - & - & - & - & - & - & - & - & - & - & - & - & - & - & - & - & 0.3 & - & - & - & - & - & 0.1 & - & - \\
\hline Myrothecium spp. & - & 23.9 & - & 17.8 & - & 10.7 & 3.7 & 40.0 & 3.7 & 7.8 & 15.6 & 0.7 & 25.2 & 7.0 & 2.6 & - & 5.2 & 2.6 & - & 1.5 & 21.1 & 20.0 & 12.3 & 37.5 & 12.1 & 4.7 & 33.2 & 4.5 & 21.0 & 14.5 & 8.8 & 28.4 & 12.0 & 1.5 & 23.8 & 2.6 & 16.2 & 11.0 \\
\hline Nigrospora & - & 0.3 & 0.1 & 0.1 & - & - & 0.4 & 1.7 & 0.4 & 0.4 & - & 0.4 & 0.7 & 1.9 & - & . & - & 0.4 & - & - & 0.4 & 0.7 & 0.1 & 0.1 & 0.1 & 0.6 & 0.7 & 0.1 & 1.0 & 1.0 & - & 0.1 & 0.1 & 0.6 & 0.5 & 0.5 & 0.8 & 0.3 \\
\hline Oedocephalum sp. & 1.2 & $\cdot$ & 1.5 & $\cdot$ & - & $\cdot$ & 0.4 & - & - & - & - & - & - & 0.4 & - & 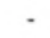 & - & - & - & - & - & - & 0.1 & - & - & - & - & - & - & $\cdot$ & 0.1 & - & - & - & - & - & 0.4 & - \\
\hline Paecilomyces sp. & 0.2 & $\cdot$ & 0.1 & - & 0.1 & $\cdot$ & 0.4 & - & - & - & - & - & - & 0.4 & - & - & - & - & - & - & - & $\cdot 1$ & 1.0 & 0.2 & 0.1 & 0.1 & 0.1 & - & 0.2 & 0.1 & 0.9 & - & - & 0.1 & - & - & 0.2 & 0.2 \\
\hline Parapericonia augu & - & - & - & - & - & - & - & - & - & . & - & - & - & -1 & - & 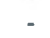 & . & - & - & - & - & . & 0.1 & - & - & - & - & - & . & - & - & - & - & . & - & - & - & - \\
\hline Penicillium spp. & 0.7 & 0.8 & 2.4 & 0.4 & 1.4 & 0.3 & 0.4 & 1.7 & 0.4 & 0.7 & 0.4 & 1.5 & 0.7 & - & 0.7 & - & 0.4 & - & - & 6.3 & - & - & 3.4 & 3.8 & 2.1 & 2.5 & 0.9 & 6.9 & 3.7 & 3.1 & 1.7 & 3.2 & & 0.5 & 0.2 & 4.8 & 0.2 & 0.8 \\
\hline Periconia spp. & 4.0 & 0.2 & 9.9 & 0.1 & 7.1 & 3.0 & 3.0 & - & - & - & - & - & 3.4 & 3.3 & 2.2 & - & 0.4 & 0.7 & - & - & 0.4 & 1.1 & 3.3 & - & 0.4 & 0.1 & $\cdot$ & 0.2 & 0.7 & 0.9 & 2.2 & - & 0.5 & 0.2 & 0.1 & 0.1 & - & 0.1 \\
\hline $\begin{array}{l}\begin{array}{l}\text { Pithom } \\
\text { atro-c }\end{array} \\
\text { a }\end{array}$ & - & - & - & - & - & - & - & - & - & - & - & - & - & - & 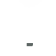 & . & - & $\because$ & . & - & - & $\because$ & & 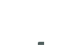 & - & & - & - & - & & & . & - & .1 & & - & & - \\
\hline chart & 2.1 & 25.1 & 4.1 & 17.3 & 5.3 & 65.2 & 3.7 & 40.0 & 4.8 & 8.9 & 14.1 & 9.6 & 14.1 & 8.2 & 4.8 & & 5.2 & 3.7 & 5.6 & 6.7 & 11.1 & 11.1 & 6.0 & 4.8 & 2.3 & 3.8 & 4.6 & 6.6 & 2.7 & 2.7 & 3.4 & 5.1 & 2.1 & 4.7 & 3.9 & 4.0 & 2.7 & 2.2 \\
\hline cynodc & • & I & - & $\cdot$ & • & $\cdot$ & - & - & - & - & - & - & - & -1 & - & - & - & 2.0 & - & - & - & - & - & - & - & 0.1 & 0.1 & 0.3 & - & 0.1 & 0.1 & - & - & .1 & - & 0.1 & - & 0.1 \\
\hline inicola & - & - & - & - & - & - & - & - & - & - & - & - & - & . & 0.4 & - & . & - & - & - & - & I & 0.1 & - & - & 0.1 & - & .1 & - & - & - & - & - & 0.1 & - & - & - & - \\
\hline$k o$ & 0.5 & 0.1 & 0.2 & 1.3 & 0.2 & 0.8 & - & - & - & - & - & - & & - & - & - & - & - & - & - & 0.4 & - & 0.4 & - & - & 0.1 & 0.3 & 0.5 & 0.4 & - & 0.2 & - & 0.1 & 0.1 & & 0.1 & 0.4 & 0.1 \\
\hline maydict & - & - & - & - & - & -1 & - & - & - & - & - & - & - & - & - & - & - & - & - & - & . & - & . & - & - & • & - & • & - & - & - & . & - & 0.1 & 0.1 & - & - & - \\
\hline Rhino & 1.3 & & 1.1 & 2.1 & 1.7 & - & 0.4 & - & 0.7 & - & 0.4 & - & & 0.4 & 0.4 & 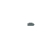 & 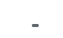 & 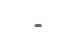 & 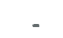 & 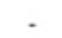 & 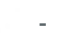 &. & 2.0 & . & 0.1 & - & 0.1 & 0.1 & 1.0 & 0.3 & 0.1 & - & - & . & - & - & 0.1 & 0.1 \\
\hline Scopulariopsis brevicaulis & - & 0.1 & $\cdot$ & $\cdot$ & - & $\cdot$ & - & - & - & - & - & - & - & - & - & - & - & - & - & - & - & 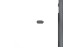 & - & 0.1 & 0.1 & 0.2 & 0.1 & - & 0.1 & 0.1 & - & - & - & 0.1 & - & 0.1 & - & 0.1 \\
\hline $\begin{array}{l}\text { Spegazzini } \\
\text { parkeri }\end{array}$ & - & - & - & - & 0.1 & -1 & - & - & . & - & - & - & - & - & 7 & & - & - & - & - & 0.4 & - & - & & - & - & - & - & - & & - & - & & & & & - & - \\
\hline tessartho & 0.4 & - & 0.1 & - & 0.5 & . & 0.4 & - & 0.7 & - & 0.4 & & & 0.4 & 0.4 & 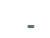 & & & & 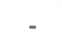 & 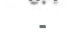 & - & 0.1 & 0.1 & 0.4 & 0.1 & - & 0.2 & 0.1 & - & - & - & 0.9 & 0.1 & - & 0.2 & - & 0.1 \\
\hline $\begin{array}{l}\text { Stachybotrys chartaruim } \\
\text { Stemphylium }\end{array}$ & - & - & - & - & - & -1 & - & - & - & - & - & - & - & - & - & - & 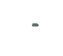 & 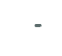 & . & . & 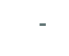 & 1 & 0.1 & - & 0.1 & 0.1 & - & 0.1 & 0.2 & - & - & - & - & 0.2 & 0.1 & - & 0.1 & - \\
\hline botryosur & - & - & - & - & 0.1 & -1 & - & - & - & - & - & - & - & - & . & - & - & - & - & 0.7 & - & - & - & - & - & - & 0.7 & - & 1 & - & - & - & - & - & - & - & - & - \\
\hline & 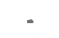 & 0.2 & - & 0.6 & . & 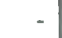 & 3.0 & - & - & - & - & - & - & - & 4.1 & - & 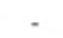 & - & - & - & - & 0.4 & - & 0.3 & 0.2 & 0.1 & - & 0.4 & 7 & - & - & 0.1 & 0.3 & 0.2 & 0.3 & 0.1 & 0.2 & 0.5 \\
\hline Taeniolella sp & 3.0 & - & 1.1 & 0.8 & 0.4 & - & - & - & - & - & - & - & . & 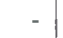 & - & - & - & - & - & - & - & -1 & 0.6 & - & - & - & - & - & 0.2 & - & 0.9 & - & 0.1 & - & - & - & - & - \\
\hline & 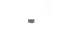 & 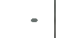 & - & - & 0.1 & - & - & - & - & - & - & - & - & - & - & 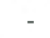 & 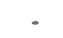 & 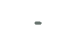 & - & - & - & - & $i$ & - & - & - & - & - & - & - & - & - & - & - & - & - & - & - \\
\hline Torula herbarum & 0.3 & - & 1.8 & - & 0.4 & - & 3.0 & - & - & - & - & - & & - & - & - & - & - & - & - & - & - & 1 & - & - & - & - & 0.1 & 0.1 & - & - & - & - & 0.1 & - & 0.1 & - & - \\
\hline Trichoderma & - & 0.3 & - & - & - & 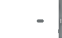 & 0.8 & 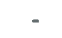 & - & - & - & - & - & 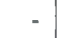 & 0.4 & 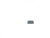 & . & 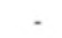 & - & - & 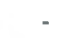 & 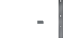 & 1.7 & 1.8 & 0.8 & 1.3 & 1.2 & - & - & 0.5 & 1.5 & 0.8 & 0.2 & 0.2 & 0.7 & 0.3 & 0.3 & 0.8 \\
\hline $\begin{array}{l}\text { Trichothecium roseum } \\
\text { Ulocladium }\end{array}$ & - & 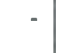 & - & - & - & -1 & - & - & - & - & - & - & - & - & 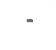 & $\cdot$ & 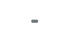 & - & - & - & . & 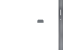 & 0.1 & - & 0.7 & 0.1 & . & - & 0.1 & 0.1 & $\cdot$ & $\cdot$ & 0.6 & 0.2 & 0.1 & 0.1 & 0.1 & 0.2 \\
\hline atrum & . & 0.2 & - & 0.2 & - & -1 & - & - & - & . & - & - & - & - & 0.4 & - & - & - & - & 1. & 0 & & & - & - & - & - & - & - & - & - & - & - & - & - & - & - & - \\
\hline 年 & 01 & - & 0.1 & - & 0.7 & - & 0.4 & 16.7 & - & - & - & - & . & . & - & - & 3.3 & 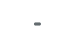 & 3.3 & 0.4 & 0 & - & 1 & 0.1 & 0.1 & 0.1 & 0.1 & 0.1 & . & 0.1 & - & - & 0.1 & - & 0.1 & 0.1 & - & 0.1 \\
\hline Volutella colle & 1. & - & 0.7 & 6.6 & 0.4 & 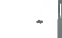 & 1.9 & - & 8.9 & - & 18.9 & 1.5 & 4.1 & 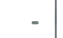 & - & 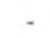 & - & 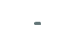 & - & - & 0.4 & - & 0.2 & 4.0 & 1.4 & 1.0 & - & 0.9 & 0.8 & 0.7 & 0.2 & 2.5 & 2.9 & 0.6 & 17.1 & - & 0.4 & 0.2 \\
\hline Volutina sp. & 0.3 & $\cdot$ & 0.1 & - & 0.5 & - & - & - & - & - & - & - & - & - & - & - & - & - & - & - & - & - & 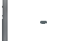 & - & - & - & 17.5 & - & - & - & 3.9 & - & - & 0.1 & - & - & - & 0.2 \\
\hline & & & & & & & & & & & & & & & & & & & & & & & & & & & & & & & & & & & & & & \\
\hline & 0.1 & - & - & - & 0.1 &. & - & - & - & - & - & - & - & - & - & - & - & - & - & - & - & - & 1.2 & - & - & - & - & 0.1 & 0.1 & 0.2 & - & - & - & - & - & - & - & - \\
\hline Hyphomycere no. 1 & - & . & - & - & - & & - & - & - & - & - & - & - & . & - & - & 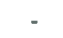 & 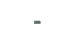 & - & - & - & & 0.1 & 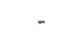 & - & - & - & - & - & - & - & - & - & - & - & - & - & - \\
\hline
\end{tabular}


TABLE 6.-Percentage of the total number of samples taken for the Coelomycetes (1978-1981)

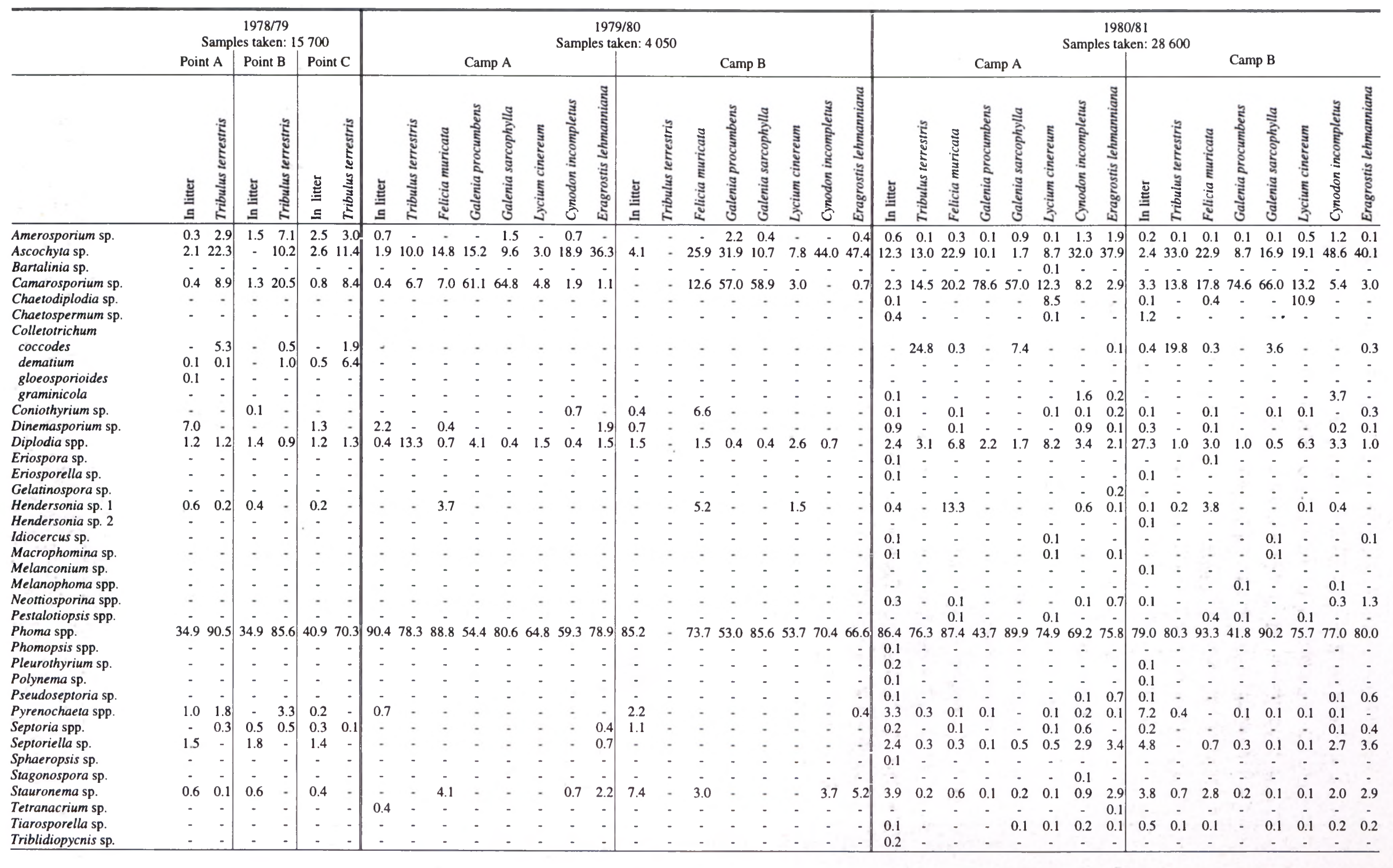


TABLE 7.-Percentage of the total number of samples taken for the Ascomycetes, Zygomycetes, Mycelia Sterilia, Myxomycetes and unknown fungi (1978-1981)

\begin{tabular}{|c|c|c|c|c|c|c|c|c|c|c|c|c|c|c|c|c|c|c|c|c|c|c|c|c|c|c|c|c|c|c|c|c|c|c|c|c|c|c|}
\hline & \multicolumn{6}{|c|}{$\begin{array}{c}1978 / 79 \\
\text { Samples taken: } 15700\end{array}$} & \multicolumn{16}{|c|}{$\begin{array}{c}1979 / 80 \\
\text { Samples taken: } 4 \text { 050 }\end{array}$} & \multicolumn{16}{|c|}{$\begin{array}{c}\text { 1980/81 } \\
\text { Samples taken: } 28600\end{array}$} \\
\hline & \multicolumn{2}{|c|}{ Point A } & \multicolumn{2}{|c|}{ Point B } & \multicolumn{2}{|c|}{ Point C } & \multicolumn{8}{|c|}{ Camp A } & \multicolumn{8}{|c|}{ Camp B } & \multicolumn{8}{|c|}{ Camp A } & \multicolumn{8}{|c|}{ Camp B } \\
\hline & $\begin{array}{l}\text { ⿹气 } \\
\underline{\underline{\Xi}}\end{array}$ & 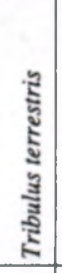 & 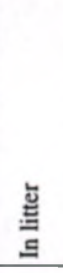 & 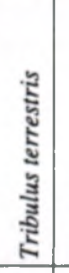 & $\begin{array}{l}\text { 乌્ } \\
\text { 으 }\end{array}$ & 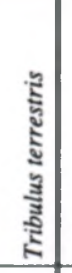 & $\begin{array}{l}\text { 駦 } \\
\text { 品 }\end{array}$ & 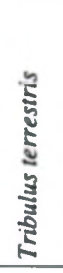 & 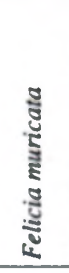 & 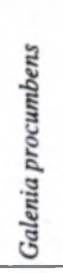 & 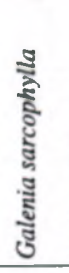 & 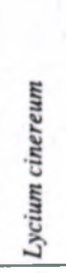 & 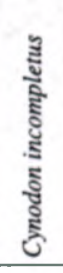 & 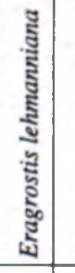 & $\begin{array}{l}\text { 总 } \\
\text { 品 }\end{array}$ & 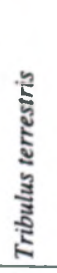 & 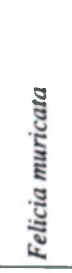 & 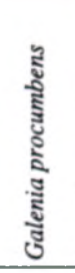 & 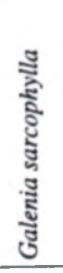 & 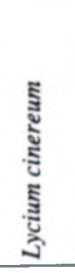 & 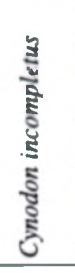 & 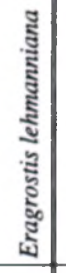 & $\begin{array}{l}\text { 窇 } \\
\text { 드 }\end{array}$ & 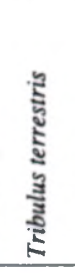 & 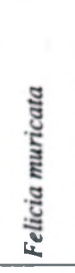 & 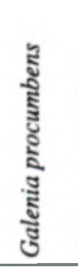 & 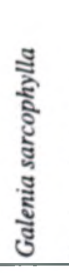 & 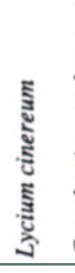 & 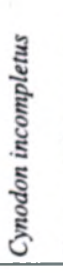 & 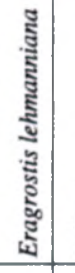 & 氖 & 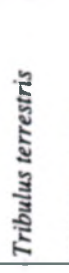 & 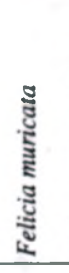 & 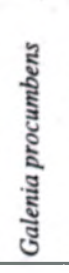 & 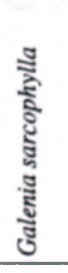 & 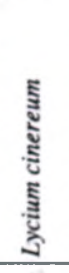 & 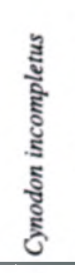 & 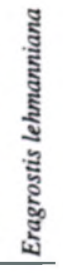 \\
\hline Ascomycetes & & & & & & & & & & & & & & & & & & & & & & & & & & & & & & & & & & & & & & \\
\hline Ceratocustis sn & - & - & - &. & - & $\cdot$ & - & - & - & - & - & - & - & $\cdot$ & - & - & - & . & - & . & - & - & - & . & . & - & . & - & - &. & 0.1 & - & - & - & - & . & - & - \\
\hline Chaetomium spp. & 0.7 & - & 0.1 & - & 0.5 &. & 0.7 & - & - & 0.7 & - & - & - &. & - & - & 0.4 & 1.9 & 0.4 & 0.4 & 0.4 & - & 0.3 & 0.2 & 0.4 & 0.5 & 0.7 & 0.1 & 0.3 & 0.4 & 0.5 & - & 0.2 & 0.1 & 0.1 & 0.2 & 0.2 & 0.2 \\
\hline ieria spp. & - &. & - & - & - & - & 3.0 & - & - & - & . & - & - & 1.1 & - & - & - & - & - & - & - & - & 2.4 & - & - & - & - & - & 0.1 & 0.1 & 1.0 & - & - & - & - & - & 0.1 & 0.6 \\
\hline Leptosphaerulina spp. & 3.6 & 27.1 & 2.2 & 30.8 & 2.13 & 32.2 & 1.1 & 5.6 & 33.7 & 33.3 & 6.33 & 35.6 & 44.4 & 10.4 & 1.9 & - & 21.5 & 13.3 & 6.7 & 34.13 & 33.31 & 13.0 & 2.5 & 10.6 & 18.62 & 22.6 & 3.71 & $10.3 \mathrm{I}$ & 17.6 & 6.2 & 2.5 & 5.91 & 12.53 & 35.2 & 1.8 & 7.3 & 14.0 & 4.6 \\
\hline Mycosphaerella spp. & - & 0.2 & - & 0.5 & - & 1.2 & - & - & 0.7 & 1.9 & -1 & 10.0 & 1.4 & $\cdot$ & - & - & 0.4 & 0.4 & 10.0 & 2.6 & - & - & 0.9 & 0.7 & 0.8 & 2.5 & - 1 & 15.0 & 0.3 & 0.2 & 1.2 & 0.2 & 0.4 & 1.4 & 0.1 & 12.9 & 0.4 & 0.1 \\
\hline Ophiobolus circii & - & - & - & 0.1 & 0.1 & -1 & - & - & - & - & - & - & - & - & - & - & - & - & - & - & - & - & - & - & - & - & - & - & - & - & 0.1 & - & - & - & - & - & - & - \\
\hline Platyspora permunda & - & $\cdot$ & 0.3 & - & 0.3 & - & - & - & - & - & - & - & - & - & - & - & - & - & - & - & - & - & - & - & - & 0.3 & - & 0.1 & - & 0.1 & - & - & - & - & - & - & - & - \\
\hline Pleospora herbarum & - & - & - & - & - & - & - & - & - & - & - & - & 0.4 & - & - & - & - & - & . & - & - & - & - & - & - & - & - & - & - & - & 0.1 & - & - & 0.1 & - & - & - & 0.1 \\
\hline Pleospora sp. & 0.1 & - & - & - & - & - & - & - & - & - & - & - & - & - & - & - & . & . & - & - & - & - & - & - & - & - & - & - & 0.1 & 0.1 & - & - & - & - & - & - & 0.1 & 0.1 \\
\hline Saccobolus sp. & 0.4 & - & 0.3 & - & 0.7 & - & - & - & - & - & - & - & - & - & - & . & - & - & - & - & - & 0.7 & 0.3 & - & - & - & - & - & - & 0.1 & 0.1 & - & - & - & - & - & 0.1 & - \\
\hline Sordaria fimicola & $\cdot$ & $\cdot$ & 0.1 & - & $\cdot$ & $\cdot$ & 1.9 & - & - & - & 1.1 & - & - & - & - & - & - & - & - & - & - & - & 0.1 & - & $\cdot$ & 0.1 & 0.7 & - & - & - & 0.1 & - & - & - & $\cdot$ & $\cdot$ & $\cdot$ & - \\
\hline Zygo & & & & & & & & & & & & & & & & & & & & & & & & & & & & & & & & & & & & & & \\
\hline Cunninghamella sp. & 0.2 & . & 0.1 & - & - & - & 0.7 & - & - & - & 0.7 & - & . & - & 0.4 & - & . & . & . & . & . & - & 0.1 & - & - & - & - & - & - & - & 0.1 & - & - & - & 0.2 & - & - & - \\
\hline Mortierella spp. & - & - & - & - & - & - & 0.4 & - & - & - & - & - & 0.7 & - & - & - & - & - & - & - & - & - & 2.1 & 0.7 & 0.2 & 0.2 & 1.1 & 0.1 & 0.1 & - & 1.6 & - & - & - & 0.1 & - & 0.8 & 0.1 \\
\hline Mucor spp. & 1.9 & 0.2 & 1.6 & - & 2.5 & - & - & - & - & - & - & - & - & - & . & - & - & . & - & . & - & - & 1.0 & 0.3 & 0.3 & 0.2 & - & 0.1 & 0.1 & 0.2 & 1.9 & 0.1 & 0.1 & - & 0.1 & - & 0.1 & 0.1 \\
\hline Rhizopus stolonifer & - & 0.1 & - & - & - & - & - & 6.7 & - & - & - & - & - & 0.7 & - & - & - & 1.5 & 0.7 & 5.6 & - & 0.4 & 1.5 & 5.2 & 2.4 & 0.1 & 5.0 & 0.7 & 1.8 & 3.6 & 2.2 & 1.2 & 0.1 & 0.1 & 2.5 & 0.5 & 0.9 & 1.6 \\
\hline Rhizomucor sp. & - & - & - & - & - & - & - & - & - & - & - & - & - & - & - & - & - & - & - & - & - & - & - & - & - & - & - & 0.1 & - & - & - & - & - & 0.1 & - & 0.1 & - & - \\
\hline Myc & & & & & & & & & & & & & & & & & & & & & & & & & & & & & & & & & & & & & & \\
\hline Papul & - & - & - & - & - & - & - & - & - & - & - & - & - & - & - & - & - & - & - & - & - & - & $0 . i$ & - & - & - & $\therefore$ & - & - & $\therefore$ & - & - & - & - & $\therefore$ & - & - & - \\
\hline Rhizoctonia spp & 2.6 & - & 1.5 & - & 5.9 & - & - & - & - & - & - & - & - & - & - & - & - & - & - & - & - & - & 11.9 & 1.6 & 0.1 & 0.7 & 0.4 & - & 0.4 & $\begin{array}{lll}0.1 & 1\end{array}$ & 12.7 & 0.2 & - & - & 0.3 & - & - & 0.1 \\
\hline Sclerotium rolfsii & - & - & $\cdot$ & - & - & - & - & - & - & - & - & - & - & - & - & - & - & - & - & - & - & - & 0.2 & - & - & - & - & 0.1 & - & -1 & 0.5 & - & - & - & - & - & 0.1 & - \\
\hline Myxomycetes & - & - & - & $\cdot$ & - & $\cdot$ & 0.4 & - & - & - & - & - & - & - & 1.1 & - & - & - & - & - & - & - & 1.2 & - & 0.9 & - & 0.1 & - & - & $\cdot$ & 1.8 & 0.1 & 0.3 & $\cdot$ & $\cdot$ & - & 0.1 & - \\
\hline asidiomycetes & - & - & - & - & - & . & - & . & . & - & - & . & 0.4 & . & - & - & - & . & - & - & . & - & 0.1 & - & . & - & - & - & . & - & - & - & - & . & - & - & 0.1 & 1.2 \\
\hline Puccini & - & - & - & - & - & - & 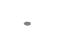 & 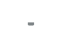 & 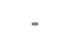 & - & - & & - & - & - & - & & - & - & - & - & - & 0.4 & - & - & - & - & 1.5 & 5.0 & 0.3 & 0.1 & - & 0.1 & - & - & 0.2 & 3.6 & 0.1 \\
\hline Ustilaginales & - & - & - & - & - & - & - & - & - & - & - & - & - & - & - & - & - & - & - & - & - & - & - & - & 0.8 & - & - & - & - & - & - & - & - & - & - & - & 0.1 & - \\
\hline & & & & & & & & & & & & & & & & & & & & & & & & & & & & & & & & & & & & & & \\
\hline etes & 4.9 & 0.5 & 4.3 & 0.5 & 3.2 & 0.3 & 0.7 & - & 3.0 & . & . & - & 2.6 & 1.5 & 0.7 & . & . & . & . & 0.7 & 0.7 & 5.8 & 2.2 & . & 0.1 & 0.2 & 0.1 & 0.3 & 0.6 & - & - & - & 0.4 & 0.3 & 0.2 & 0.3 & 1.0 & 2.7 \\
\hline a d t & - & - & - & $\cdot$ & - & - & - & - & - & - & - & 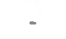 & - & - & - & - & - & - & - & - & - & - & 0.1 & - & $\cdot$ & - & - & - & - & - & 0.1 & - & - & - & - & - & - & - \\
\hline elomycetes sp. 1 & - & - & - & - & - & - & - & - & - & - & - & - & . & - & - & - & . & - & - & . & - & - & - & - & - & - & 0.1 & - & - & - & -6 & 0.1 & - & - & - & - & - & - \\
\hline Delomycetes sp. 2 & - & - & - & - & - & - & - & - & - & - & - & - & - & - & - & - & - & - & - & - & . & - & - & - & 0.1 & - & - & 0.1 & 0.1 & 0.2 & - & - & 0.4 & - & $\therefore$ & 0.1 & - & 1.2 \\
\hline elomycetes sp. 3 & - & - & . & - & - & -1 & - & - & - & - & - & - & - & - & - & - & - & - & - & - & - & - & . & - & 0.2 & - & - & - & - & - & - & - & 0.5 & - & 0.1 & 0.1 & 0.4 & 5.0 \\
\hline es sp. 4 & - & - & - & - & - & -1 & - & - & - & - & - & - & - & - & - & - & . & - & - & - & - & - & - & - & - & - & - & - & - & 0.1 & - & - & - & $\therefore$ & - & - & - & - \\
\hline elomyceres sp. 5 & - & - & - & - & - & - & - & - & - & - & - & - & - & - & - & - & - & - & - & - & - & - & - & - & $0 . \mathrm{i}$ & - & - & - & - & - & - & - & - & 0.1 & - & - & - & - \\
\hline Delomycetes sp. 6 & 0.3 & - & 0.3 & - & 0.3 & -1 & - & - & - & - & - & - & - & - & - & - & - & - & - & - & - & - & - & - & - & - & 2.0 & - & - & - & - & - & - & $\therefore$ & - & 2.5 & - & - \\
\hline Mycelia Sterilia & - & 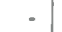 & - & - & - & 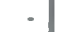 & - & - & - & 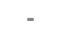 & - & 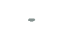 & - & 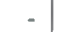 & 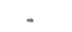 & 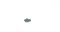 & - & - & 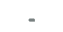 & 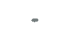 & 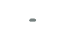 & & - & 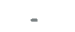 & - & 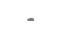 & - & - & - & - & - & - & - & 0.1 & - & - & - & - \\
\hline
\end{tabular}


ported in other surveys of fungal populations are negligible.

Dickinson (1967) could correlate an increase in frequency of Stemphylium botryosum with records of its perfect state, Pleospora herbarum, on Pisum leaves. In the present survey the relation between Leptosphaerulina chartarum and its anamorph only became clear after conclusion of the sampling programme. All specimens of Leptosphaerulina were not identified to species level. It can, however, be assumed that $L$. chartarum was more prevalent at times when incidences of Pithomyces chartarum reached peaks, e.g. late summer and early winter (February to May), seeing that $P$. chartarum and Leptosphaerulina spp. were more prevalent then.

\subsection{Photosensitization}

Crawley \& Woolford (1965) stipulated a minimum temperature of $12.2^{\circ} \mathrm{C}$ or more on three consecutive days together with $3.76 \mathrm{~mm}$ of rain as a danger period for the development of the facial eczema in sheep. The same conditions were assumed to be necessary for the development of 'geeldikkop' in local sheep. No such conditions were recorded and no cases of photosensitization on the sampled pastures were reported.

Another factor which could play a role was the presence of saponins in the T. terrestris plants (Watt \& BreyerBrandwijk 1962). Aas \& Ulvund (1989) speculated that P. chartarum, especially the sporidesmin present on bog asphodel and saponins, may be involved in the aetiology of alveld (a hepatogenous photosensitivity) in Norway. Since then, Kellerman et al. (1991) have shown that saponins on their own are able to induce hepatogenous photosensitivity in some sheep. The importance of sporidesmins has, however, not diminished as all sheep in that trial did not react positively. Kellerman et al. (1991) found that fresh $T$. terrestris, both on its own and with sporidesmin, caused 'geeldikkop' in sheep.

\section{CONCLUSIONS}

The survey highlights the wealth and variety of fungi found in this inhospitable environment. The large numbers of genera found is due to the wide range of materials sampled. A peculiarity was that virtually the same number of genera of Coelomycetes and Hyphomycetes was found. Nag Raj (1981) noted that Coelomycetes were more prevalent in dry climates, a fact which has been confirmed here. This phenomenon can be attributed to the adaptation of the fungus in shielding its conidiogenous cells and hyaline conidia from the high UV-radiation in the predominantly cloudless Karoo region by developing a conidioma. Very few synnematous genera of the Hyphomycetes were recorded. An analogue in the Hyphomycetes is the protective mechanism of melanin, because a great proportion of the species present have melanized conidia.

This is the first survey in southern Africa in which such a high proportion of fungi identified belonged to the Coelomycetes. The invidual genera could be determined to a great extent using Sutton's keys (1980). Numerous new records for South Africa were registered.
The suitability of litter as a substrate for fungal growth, even under these harsh climatic conditions, was an indication of the role fungi play as agents in the breakdown of organic matter. The wide spectrum of fungal genera noted on the litter gave an indication of what was present on substrates not sampled separately.

This survey demonstrated the persistent presence of Pithomyces chartarum on various substrates in the Karoo. This is a very important finding in view of its toxicity. The teleomorph of this fungus, Leptosphaerulina chartarum, was found during this study (Roux 1985a). P. chartarum was recovered from $T$. terrestris leaves without lesions. This possible endophytic symbiosis of certain strains may indicate its mycotoxicological, opposed to pathogenic (Haware \& Sharma 1973) nature and also of the existence of purely saprophytic strains. This survey illustrates the importance of intensive studies of fungal populations.

\section{ACKNOWLEDGEMENTS}

The senior author wishes to thank the following for invaluable assistance: the then Director, Karoo Region, Dr P. Roux, who appointed Mr Andries Barnhoorn to assist locally in the taking of samples - the latter did a marvellous job; the late Dr Marius van Tonder, State Veterinarian, Regional Diagnostic Office, who kept the sheep under surveillance for clinical signs of 'geeldikkop' for five years; the late $\mathrm{Mr}$ (Oom Piet) P.J.J. van der Westhuizen, Mycology Unit, PPRI, Pretoria, who painstakingly and scrupulously prepared the Petri dishes and plated out those thousands and thousands of samples over years; Mrs Marjan Botes (née De Oude) and Miss Elsie van der Westhuisen, Mycology Unit, PPRI, Pretoria, who assisted with the extraction of sporidesmin; Mr John Pullen, Institute for Climate, Soil and Water, who collected the meteorological data; the late Mr Jo Minné, who was in the Analytical Chemistry Unit, Toxicology Division, Onderstepoort Veterinary Research Institute, Pretoria, for continual assistance and advice on the extraction of sporidesmin; the late Dr LAP Anderson, for discussions and advice; and lastly my colleagues for undaunting support. This paper forms part of a Ph.D degree accepted at the Rand Afrikaans University as submitted by the first author.

\section{REFERENCES}

AAS, O. \& ULVUND, M.J. 1989. Do microfungi help to induce the phototoxic disease alveld in Norway? Veterinary Record 124: 563.

ACOCKS, J.P.H. 1979. The flora that matched the fauna. Bothalia 12 673-709.

ACOCKS, J.P.H. 1988. Veld types of South Africa, 3rd edn. Memoirs of the Botanical Survey of South Africa No. 57.

ANNUAL REPORT 1981. Director General, Department of Agriculture and Fisheries for the period I April 1980 to 31 March 1981 Pretoria.

BEZUIDENHOUT, H. 1977. 'n Ondersoek van die Hyphomycetes geassosieer met Cenchrus ciliaris L. M.Sc. thesis, Rand Afrikaans University, Johannesburg.

BOOTH, C. 1971. The genus Fusarium. Commonwealth Mycological Institute, Kew, England.

CRAWLEY, W.E. \& WOOLFORD, M.W. 1965. Predicting facial eczema danger periods. Proceedings of the Ruakura Farmers' Conference Week: 15-21. 
DICKINSON, C.H. 1967. Fungal colonization of Pisum leaves. Canadian Journal of Botany 45: 915-927.

DI MENNA, M.E., CAMPBELL, J. \& MORTIMER, P.H. 1970. Sporidesmin production and sporulaton by Pithomyces chartarum. Journal of General Microbiology 61 : 87-96.

DOIDGE, E. M. 1950. The South African fungi and lichens to the end of 1945. Bothalia 5: 1-1094.

EICKER, A. 1973. The mycoflora of Eucalyptus maculata leaf litter. Soil Biology and Biochemistr' 5: 441-448.

EICKER, A. 1976. The non-parasitic mycoflora of the phylloplane and litter of Panicum coloratum. Transactions of the British Mycological Society 67: 275-281.

ELLIS, M.B. 1971. Dematiaceous Hyphomycetes. Commonwealth Mycological Institute, Kew, England.

ELLIS, M.B. 1976. More dematiaceous Hyphomycetes. Commonwealth Mycological Institute, Kew England.

HAWARE, M.P. \& SHARMA, N.D. 1973. A new glume blotch of rice (Onza sativa). Plant Disease Reporter 57: 436, 437

HAWKSWORTH, D.L., KIRK, P.M., SUTTON, B.C. \& PEGLER, D.N 1995. Dictionary of fungi, 8 th edn. CAB Intemational, Oxon.

HERING. T.F. 1965. Succession of fungi in the litter of a Lake District oakwood. Transactions of the British Mycological Society 49: 185-192.

HUTCHEON, D. 1886. Report of the Veterinary Surgeon. Cape of Good Hope, G14, 1887, Cape Town.

JOHNSTON, A. \& BOOTH, C. 1983. Plant pathologist's pocketbook, 2nd edn. Commonwealth Agricultural Bureaux, International My cological Institute, Kew, England.

KELLERMAN, T.S., VAN DER WESTHUIZEN, G.C.A., COETZER. J.A.W. ROUX, C., MARASAS, W.F.O., MINNE, J.A., BATH G.F. \& BASSON. P.A. 1980. Photosensitivity in South Africa. 11 The experimental production of the ovine hepatogenous photosentivity disease geeldikkop (Tribulosis ovis) by the simultaneous ingestion of Tribulus terrestris plants and cultures of Pithomyces chartarum containing the mycotoxin sporidesmin. Ondersteport Joumal of Veterinary Research 47: 231-261.

KELLERMAN, T.S., ERASMUS, G.L., COETZER, J.A.W., BROWN, J.M.M. \& MAARTENS, B.P. 1991. Photosensitivity in South Africa. VI. The experimental induction of geeldikkop in sheep with crude steroidal saponins from Tribulus terrestris. Onderstepoort Journal of Veterinan' Research 58: 47-53.

MARASAS, W.F.O. \& SCHUMANN, I.H. 1972. The genus Pithomyces in South Africa. Bothalia 10: 509-516.

MARASAS, W.F.O., ADELAAR, T.F., KELLERMAN, T.S., MINNE, J.A., VAN RENSBURG, I.B.J. \& BURROUGHS, G.W. 1972. First report of facial eczema in sheep in South Africa. Onderstepoon Journal of Veterinary Research 39: 107-112.

MÖHR. J.D. 1982. The Karoo caterpillar Loxostega frustalis Zeller (Lepidoptera: Pyralidae) in relation to its host and its natural enemies. Ph.D. thesis, Rhodes University, Grahamstown, South Africa.
NAG RAJ, T.R. 1981. Coelomycete systematics. In G.T. Cole \& B Kendrick. Biology of the conidial fungi 1: 43-79. Academic Press, New York.

PAPENDORF, M.C. \& JOOSTE, W.J. 1974. The mycoflora of wheat ficld debris, Par 1. Bothalia 11: 201-207.

PRICE, P.W. 1975. Insect ecology: John Wiley, New York.

PUGH, G.J.F. \& MULDER, J.L. 1971. Mycoflora associated with Typha latifolia. Transactions of the British Mycological Society 57: 273-282

ROUX, C. 1977. 'n Studie van die voorkoms, verspreiding en morfologie van Pithomyces chartarum (Berk. \& M.A.Curtis) M.B.Ellis in Suid-Afrika en sommige aspekte van sy fisiologie. M.Sc. thesis, Rand Afrikaans University, Johannesburg.

ROUX, C. 1985a. Leptosphaerulina chartarum sp. nov., the teleomorph of Pithomyces chartarum. Transactions of the British Mycological Society 85 : 319-323.

ROUX, C. 1985b. The morphology and laxonomy of some fungi selected from a suney of a natural Karoo pasture. Ph.D. thesis, Rand Afrikaans University, Johannesburg.

SIVANISAN, A. 1987. Graminicolous species of Bipolaris, Cunularia. Drechslera, Exserohilum and their teleomorphs. Mycological Papers No. 158. CAB IMI, Kew. England

SOUTHWOOD, T.R.E. 1977. Habitat, the templet for ecological strategies? Journal of Animal Ecology 46: 337-365.

SUBRAMANIAN, C.V. 1971. Hyphomycetes. Indian Council of Agricultural Research, New Delhi.

SUTTON, B.C. 1980. The Coelomycetes. Commonwealth Agricultura Bureaux, International Mycological Institute, Kew, England.

SUTTON, B.C. \& GIBSON, I.A.S. 1977. Pithomyces chariarum. De scriptions of pathogenic fungi and bacteria No. 540. Commonwealth Agricultural Bureaux, International Mycological Institute. Kew, UK.

THEILER. A. 1918. Geeldikkop in sheep (Tribulosis ovium). Report on Veterinary Research. Union of South Africa 7 \& 8: 1-55.

THORNTON, R.H. \& PERCIVAL, J.E. 1959. A hepatotoxin from Sporidesmium bakeri capable of producing facial eczema in sheep. Nature, London 183: 63

THORNTON, R.H. \& ROSS, D.J. 1959. The isolation and cultivation of some fungi from soils and pastures associated with facial eczema disease in sheep. New Zealand Joumal of Agricultural Research 2: 1002-1016.

VAN DER MERWE. W.J.J., EICKER, A., MARASAS, W.F.O. \& KEL LERMAN, T.S. 1979. Aerospora of an Eragrostis cunula pasture in South Africa. Onderstepoort Journal of Veterinary Research 46: 19-25.

VAN TONDER, E.M., BASSON, P.A. \& VAN RENSBURG, I.B.J. 1972 'Geeldikkop' experimentally induced by feeding Tribulus terre. stris L. (Zygophyllaceae). Journal of the South African Veterinan Association 43: 363-375

WATT, J.M. \& BREYER-BRANDWIJK, M.G. 1962. The medicinal and poisonous plants of southern and eastern Africa. Livingstone, Edinburgh

\section{APPENDIX — Complete list of fungal taxa identified}

The actual fungus which was recorded is cited, not the sexual phase (teleomorph) if it was not found, as is recommended in the Rules of Nomenclature. ${ }^{*}$ New genera for South Africa. ${ }^{*}$ New species for South Africa

HYPHOMYCETES

\section{Acremoniella atra (Corda) Sacc. verrucosa Tognini \\ Alternaria \\ altemata (Fr.) Keissl. \\ zinniae M.B.Ellis}

Arthrobotrys superba Conda

Arthrinium saccharicola (Speg.) M.B.Ellis

Aspergillus

candidus Link

flavus Link

nidulans Eidam

niger Tiegh.

terreus Thom

spp.
Aureobasidium

pullulans (de Bany) Arnaud

spp.

Beauveria bassiana (Bals. -Criv.) Vuill.

Bipolaris

cynodontis (Marigoni) Shoemaker

hawaiiensis (MB.Ellis) Uchida \& Aragaki

papendorfii $(A a)$ Alcorn

zeicola (Stout) Shoemaker

Botrytis

state of Sclerotinia fuckeliniana (de Bany) Fuckel sp.

Candelabrella sp.

Cephalosporium sp.

Cercospora sp.

Cerebella andropogonis $C e s$

Chrysonilia sitophila (Mont.) Arx (= Monilia sitophila Mont.)

Cladonhinum foecundissimum Sacc. \& E.J.Marchal 
Cladosporium

cladosporioides (Fresen.) G.A.de Vries

herbarum (Pers.) Link

variabile (Cooke) G.A.de Vries

spp.

Curvularia

lunata (Wakker) Boedjin

tuberculata B.L.Jain**

Dactylella sp.

Dichotomphothora portulacae Mehrl. \& Fitzp. ex M.B.Ellis*

Doratomyces

stemonites (Pers. ex Fr) F.J. Morton \& G. Sm.

phlei (Graham) Shoemaker

Epicoccum nignum Link

Exserohilum rostrata Leonard \& Suggs

Fusariella cf. obstipa (Pollack) S.Hughes

Fusarium

acuminatum Ellis \& Everh. sensu Gordon

equiseti (Corda) Sacc. sensu Gordon

moniliforme E.Sheldon

semitectum Berk \& Ravanel

stoveri Booth**

subglutinans (Wollenw: \& Reinking) P.E.Nelson, Toussoun \& Marasas

Gliocladium

penicillioides Corda

roseum Bainier

Gonatobotrys simplex Corda

Graphium penicilloides Corda

Gyrothrix flagella (Cooke \& M. B.Ellis) Piroz.**

Helicomyces roseus Link

Helicoon sessile Morgan**

Hyalodendron lignicola (Diddens) de Hoog

cf. Lacellina macrospora (Berk. \& Broome) Petch.**

Memnoniella echinata (Rivolta) Galloway

Metarhizium anisopliae (Metsch.) Sorokin

Monacrosporium sp.

Monascus sp., conidial state

Moniliella $\mathrm{sp.}{ }^{* *}$

Myrothecium

carmichelii Grev.

cinctum (Corda) Sacc.**

roridum Tode ex $F r$

verrucaria (Alb. \& Schwein.) Ditmar ex Fr.

Nigrospora state of Khuskia oryzae H.J.Huds.

Oedocephalum glomerulosum (Bull.) Sacc.**

Paecilomyces sp.

Parapericonia angusii M.B.Ellis*

Penicillium

chrysogenum Thom

oxalicum Currie \& Thom

spp.

Periconia

byssoides Pers. ex Mérat

cookei E.W.Mason \& M.B.Ellis

cf. madreeya Subram.

Pithomyces

atro-olivaceus (Cooke \& Harkn.) M.B.Ellis

chartarum (Berk \& M.A.Curtis) M.B.Ellis

cynodontis M.B.Ellis

graminicola R.Y.Roy \& B.Rai

karoo Marasas \& Schumonn

maydicus (Sacc.) M.B.Ellis**

sacchari (Speg.) M. B.Ellis

Pyricularia oryzae Cavara

Rhinocladiella

state of Dictyotrichiella mansonii Scho-Schwart

cellaris (Pers. ex Gray) M.B.Ellis**

Scopulariopsis brevicaulis (Sacc.) Bainier

cf. Septofusidium elegantulum (Pidopl.) W.Gams

Spegazzinia

cf. parkeri Sivan.**

tessartha (Berk. \& M.A.Curtis) Sacc.

cf. Sporidesmium Link*

Stilbella spp.

Stachybotrys

chartarum (Ehrenb.) S.Hughes

sansivieriae Agarwal \& Sharma**

Stemphylium

state of Pleospora herbarum (Pers. ex Fr.) Rabenh.

vesicarium (Wallr.) E.G.Simmons
Taeniolella*

scripta (Karst.) S.Hughes** sp. **

Tetraploa ellisii Cooke

Torula herbarum (Pers.) Link ex Gray

Trichoderma

harzianum Rifai

Trichothecium roseum (Pers.) Link

Trichurus spiralis Hasselbr.

Ulocladium

atrum Preuss

chartarum (Preuss) E G Simmons

tuberculatum E.G.Simmons**

Volutella colletotrichoides J.E.Chilton

Volutina*

concentrica Penz et Sacc.**

sp. ${ }^{* *}$

\section{Albino fungi}

Altemaria altemata $(F r$.) Keissl.

Cladosporium cladosporioides (Fresen.) G.A. de Vries

Stachybotrys chartarum (Ehrenb.) S.Hughes

\section{COELOMYCETES}

Amerosporium concinnum $\mathrm{Petr}$

Ascochyta sp.

Ascochytulina sp.*

Bartalinia robillardoides Tussi*

Camarosporium

quaternatum (Hazsl.) Schulz.**

spp.

Chaetodiplodia sp.*

Chaetospermum chaetosporum (Pat.) A.L.Sm. \& Ramsb.*

Colletotrichum

coccodes (Wallr) S.Hughes

dematium (Pers. \& Fr.) Grove

gloeosporioides (Pers.) Sacc.

graminicola (Ces.) G.W.Wilson

Coniothyrium

fuckelii Corda

sp.

Dinemasporium*

strigosum (Pers. ex Fr.) Sacc.**

spp.**

Diplodia sp.

Eriospora leucostoma Berk \& Broome*

Eriosporella sp.*

Gelatinosporium sp.

Hendersonia sp

Idiocercus macarangae (TS. Ramakr.) B.Sutton*

Jahniella sp.*

Libertella sp.

Macrophomina phaseolina (Tassi) Goid.

Melanconium sp.

Melanophoma

karoo Papendorf \& J.W.du Toit

sp.**

Microsphaeropsis sp.

Neottiosporina masonii B.Sutton apud B.C.Sutton \& Marasas*

Pestalotiopsis

guepinii (Desm.) Stey.

sp.

cf. Phacidiella sp.*

Phaeoseptoria sp.*

Phoma

epicoccina Punit., M.C.Tulloch \& CM.Leach**

glomerata (Corda) Wollenw. \& Hochapf.

sorghina (Sacc.) Boerema, Dorenb. \& Kesteren

sp.

Phomopsis sp.

Pleurothyrium longissimum (Lib.) Bubák*

cf. Pleurothyrium sp.*

Polynema sp.*

Polystigmina rubrum (Desm.) Sacc**

Pseudoseptoria sp.*

cf. Pycnofusarium sp.*

Pyrenochaeta sp.** 
Sarcinulella cf. banksiae B.Sutton \& Alcom*

Seimatosporium sp.*

Septoria sp.

Septoriella*

junci (Desm.) B.Sutton**

sp.**

Sphaeropsis sp

Stagonospora sp.

Stauronema spp.*

cf. Tetranacrium gramineum H.J.Huds. \& B.Sutton*

Tiarosporella graminis (Piroz. \& Shoemaker) Nag Raj var. karoo B.Sutton \& Marasas

Tryblidiopycnis sp.*

Urohendersonia platensis Speg.*

\section{MYCELIA STERILIA (Agonomycetes)}

Papulospora sp

Rhizoctonia sp.

Sclerotium rolfsii Sacc

\section{ZYGOMYCETES-Mucorales}

Actinomucor elegans Shostakowiz

Cunninghamella echinulata (Thaurt.) Thaxt.

Mortierella sp.

Mucor sp.

Rhizopus stolonifer (Ehrenb.:Fr.) Vuill. var. stolonifer

Rhizomucor spp.

\section{ASCOMYCETES}

Ascotricha sp.

Ceratocystis $\mathrm{sp}$
Chaetomium

globosum Kunze

sp.

Leptosphaeria spp.

Leptosphaerulina

briosiana (Poll.) J.H.Graham \& Luttrell

chartarum Cec.Roux**

Mycosphaerella

tassiana (De Not.) Johanson

sp.

Ophiobolus sp.

Pezizales (unidentified)

Platyspora permunda (Cooke) Wehm. = Comoclathris Clem.**

Pleospora

herbarum (Pers, ex Fr) Rabenh.

sp.

Saccobolus minimus Vel.

Sordaria fimicola (Roberge) Ces. \& De Not.

\section{BASIDIOMYCETES}

Agaricoles

Aphyllophorales

Coprinus spp.

Puccinia graminis Pers.

Ustilaginales

\section{MYXOMYCETES}

Didymium sp.

Physarum cinereum (Batch.) Pers.

cf. Reticularia sp.

Stemonitis cf. smithii $T$. Macbr. 